\title{
Eesti jõuluaja sanditajad
}

Kirjutuse eesmärk on anda ülevaade eesti tavast, mida olen nimetanud sanditamiseks. Selle all mõistan endises agraarühiskonnas - kohati veel praegugi esinevaid - rituaal-tseremoniaalseid külaskäike kindlatel tähtpäevadel oma küla piires, sageli laiemaltki. Tavas osalejad olid suuremal või vähemal määral kostümeeritud. Maske sõna otseses tähenduses kasutati erandjuhul, reeglina juba 20. sajandil ja enamasti linnades. Sanditajaid kas kostitati või anti neile kaasa andeid (varasemal ajal ja külades söögikraami, 20. sajandil ja juba linnades maiustusi või raha - seda lastest - sanditajaile).

Kuigi tava oli vägagi tuntud - ja on seda paiguti tänapäevalgi - on ta jäänud uurijate vaateväljast kõrvale. 19. sajandi trükistes on kas teateid tava tuntusest või kirjeldus kohalikus esinemisest. 20. sajandil on piirdutud enamasti lühiülevaatega. Nii on käesoleva kirjutuse taotluseks olla esimene põhjalikum ülevaade tava kõikidest lõikudest. Eeltööde vähesuse tõttu on deskriptiivsus vältimatu.

Järgnev ülevaade toetub Eesti Kirjandusmuuseumi rahvaluule arhiivi ja Eesti Keele Instituudi murdearhiivi käsikirjalistele kogudele. Arvestatud ei ole helilindistatud ainestikku (selle litereerimine nõudnuks rohkem aega, kui seda kasutada oli). Sestap ongi uuemaid andmeid vähe, kuna lindistamine on kogumistöös muutunud põhivõtteks. Viitamise hõlbustamiseks on kasutatud materjal koondatud tegelaste (resp. tähtpäevade) kaupa registrisse ja nummerdatud ning numbrile viidatakse. Kui mahukuse tõttu registrit ei publitseerita, leiab kasutaja selle ERA-st (või autori valdusest).

Ülevaates on näidatud:
a) kombe levikuala (kihelkonniti),
b) kombes osalejad (arv, sugu, vanus),
c) osalejate kostüüm või maskeering,
d) osalejate ja pererahva suhtlemine ning 
e) kostitus või anded pererahva poolt - sedavõrd, kuivõrd see kogutud materjalis avaldub. Nimelt on kohapealsed kogujad piirdunud sageli üldiste tähelepanekutega, mis võimaldab kindlalt määrata küll kombe levikut, kuid jätab ebamääraseks muud aspektid. Õnneks aitab andmete hulk tasandada kombekirjelduse puudujääke: üks teade rõhutab üht, teine teist joont.

Vaatlen sanditamisi tähtpäevade kaupa läbi aasta, alates jõuluootusest ja jõuludest.

\section{1.a. Jõulueelne periood}

Jõulud on eestlaste vanemaid pühi. Püha nimetus on vana skandinaavia laen (Mägiste 2000: 589). Kuna nimetus on tuntud kõigi läänemeresoomlaste juures, peab laen olema vana (enne läänemeresoomlaste hargnemist), küündides kindlasti ristiusueelsesse perioodi. Kagu-Eestis on sälinud püha vanem omanimetus (talsipühä, s.o talvised pühad). Ilmselt on see algselt olnud talvise pööripäeva püha ja hiljem seostunud kristliku kalendriga.

Jõulud olid talurahvale sajandite jooksul tõeliseks puhkuse- ja hingetõmbeajaks. Kurnav sügistöö (viimasena rehepeks nii mõisas kui kodutalus) oli läbi, kevadised tööd alles ees. Toidulaudki oli tavalisest rikkalikum, sest saak oli salves. Mõistagi olid jõulud tavalistest pühadest pikemad: seda arvestati toomapäevast (21. XII) nuudipäevani (7. I - 14. I) (Hiiemäe 1998: 253-254; 1995: 15-16), uuemal ajal kolmekuningapäevani (6. I). Ent jõulude lõpupäevaks on peetud koguni küünlapäeva (2. II) (Hiiemäe 1998: 254; Lätt 1970: 60-62). Jõulude algust, eriti ootusi ja ettevalmistusi, seostati juba andrusepäevaga (30. XI) (Hiiemäe 1998: 237-238; Hiiemäe 1994: 252). Sellele viitab ka populaarne salmike:

Andres, aus mees, annab jõulud;

Toomas, tore mees, toob jõulud,

Peeter, pikk mees, peab jõulud,

Nuut, hiivapulk, viib jõulud! (EV 1980: 130-131, nr 322)

\section{1.a.1. Andresepäev - 30. november (1)}

Andrusepäeval ringikäijaid on nimetatud santmardid (Ruhnu), andrused, andresed (Saaremaa), andrisandid / andresandi (Rõuge). Tava on tuntud Ruhnus ja Lääne-Saaremal (14 teadet) ning Rõuges (3 teadet). Teated pärinevad 
ajavahemikust 1933-1977 (vt ka Hiiemäe 1998: 239). Teateid on: Ruhnu (1), Karja (1), Kihelkonna (3), Jämaja (9), Rõuge (3). Parim kirjeldus on Ruhnust:

Enamasti käivad poisid. Vitsaga koputavad akna pääle. Kui pererahvas tahab, laseb sisse. Mängivad ja tantsivad. Antakse õlut. Hirmutavad lapsi, käsevad midagi pääst lugeda. Pahupidi kasukad on seljas, meresaapad jalas, pahupidi müts pääs, õlgedest rihm ümber ja kalakessid pääs. (Reg 1.1). Sugu-mehed, poisid-on nimetatud ainult mõnes teates $(\operatorname{Reg} 1.3,6,9)$.

Ühes teates kõneldakse meeste riietesse panemisest, millest võib järeldada, et tegemist on tüdrukutega (Reg 1.14), kuid siin näikse segunenud andreseks käimine mardisanditamisega (soovitakse perele viljaõnne, karjaõnne ja kirjusid tallesid). Valdav enamik teateid kõneleb andreste käimisest, seega käidi hulgakesi. Paraku ei nimetata arvu. Ilmselt polnud see kindel, vaid johtus soovijate hulgast. Juhti või eestvedajat ei märgita.

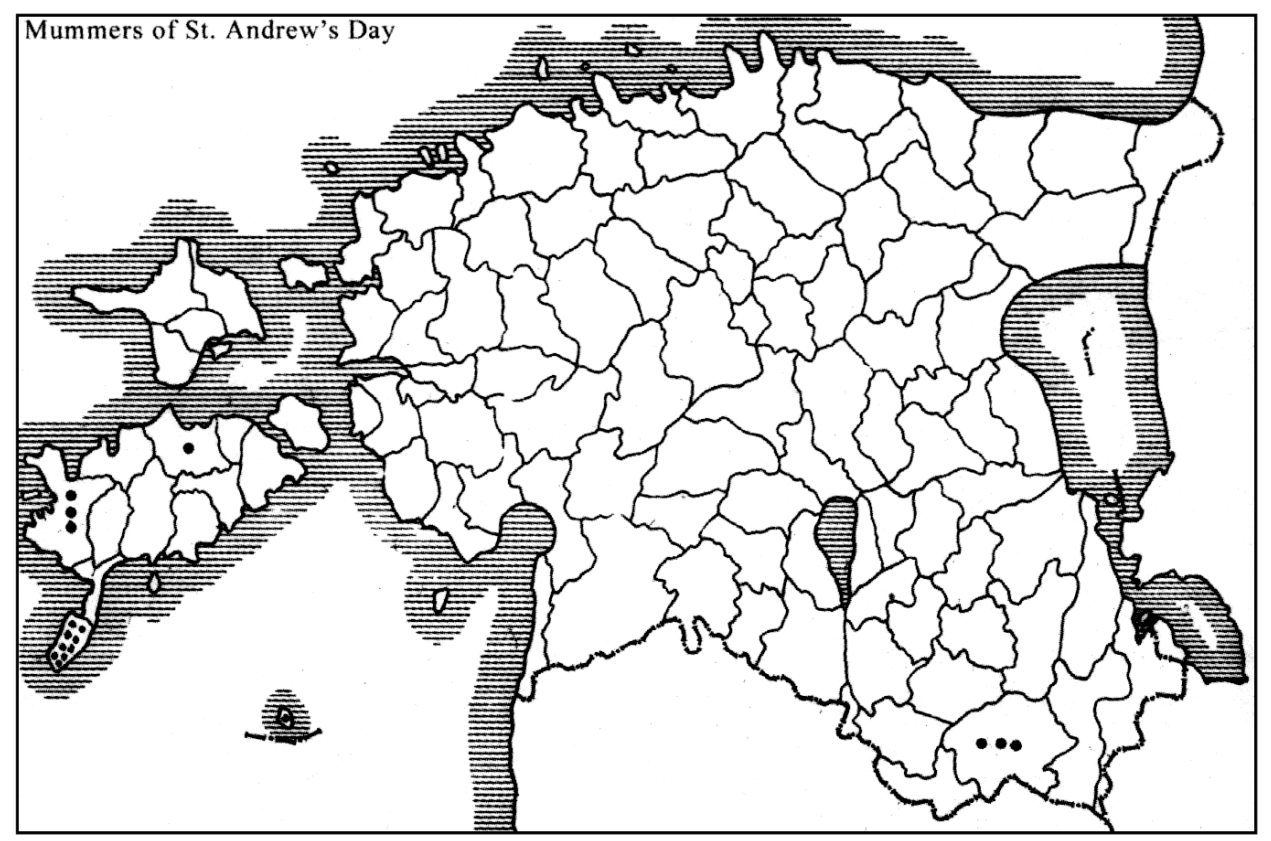

Andresed. Ülo Tedre koostatud kaart. 
Rõivastest nimetatakse vanu, näruseid riideid (Reg 1.10, 11, 12). Ühe teate järgi olnud andrestel tahmatud näod ja traadiga kinnitatud saba taga (Reg 1.6). Üks teade nimetab tavalisi riideid (Reg 1.5). Sage on võrdlemine martidega (Reg 1.1, $6,7,8)$. Ühe teate järgi käinud andres hargiga (Reg 1.2), teine (1.5) aga eitab seda. Ahjuhargile viitab aga eriti Saaremaal tuntud ütlus:

Mart tuleb kaseotstega,

Kadri kadakatega,

Lutsi luuavarrega,

Andres ahjuhargiga,

Toomas tooripuuga. (EV 1983: 279-280, nr 64444).

Teates (1.3) on tegemist jutustaja (70 aastat vana) eksimusega: andrusepäeva asemel kõneleb ta toomapäevast:

Andrusepäev: siis keidi mööda küla, mihed keisid, vett oli toobriga seljas pidand olema. Toodud vett tuppa suur igavene toobritäis ja pane kus sa tahad. Oli ka vaadatud järel, kas käsitöösid ka tehtud on.

Tegevusest on ainult mõni, juba tsiteeritud (1.1 ja 3) teade, lisaks mainitakse ühes veel tantsimist (1.12). Andreseid kostitati õllega (1.1), ountega (1.7), pähklitega (1.10.12), ubadega (1.10), verepallide e verekäkkidega $(1.10,11,12)$. Kord mainitakse ka raha (1.12).

Tavale ei leia väliseeskuju. Pigem on siin lähtutud teistest sanditamistest, mida just Saaremaal ohtrasti leidub. Andrusepäev on umbes nädal pärast kadripäeva, mis on tüdrukute sanditamispäev, ja kaks nädalat enne lutsipäeva, mis on samuti tüdrukute sanditamispäev. Nii oli andrusepäev sobiv poiste või meeste ringikäimiseks. Ilmselt seostub andreseks käimine jõulu-ettevalmistustega.

Tava ei tundu olevat eriti vana. Näiteks F. J. Wiedemanni suurteos Aus dem inneren und äusseren Leben der Ehsten (1876), mis hõlmab oluliselt ka varasema trükisõna, ei tea andrestest kui santmartideest midagi. Ent tava oli tuntud nii vähestes kihelkondades, et see ei tarvitsenud balti-saksa kodu-uurijatele silma torgata. See seletaks tava suhteliselt hiliseid fikseeringuid. Vähene andmestik võimaldab kahesugust seletust: hilist teket (19. sajandil?) või põlist püha, mis 19. sajandil hakkas juba taanduma. Teise maailmasõja-aegsed sundevakuatsioonid just nendest kihelkondadest, kus tava tunti, ei soodustanud selle püsimist. Sestap võib nentida, et tänaseks on komme hääbunud. Seda teavad veel vaid vähesed vanurid, kuid tegelikkuses see enam ei toimi.

Kagu-Eestist pärineb kolm ebamäärast teadet andrisantidest $(1.15,16,17)$, kes käisid (jõuluõhtul) vaestele andeid (kingitusi) viimas. Rahvasuu järgi on see läti tava. Teated pärinevad segaasustusega küladest (kolmest teatest kahes märgitakse sõnaselgelt tava täitjatena lätlasi). Eestist on tava praktiliselt tundmatu. 


\section{1.a.2. Luutsinapäev - 13. detsember (2)}

Luutsinapäeval - lutsia-, lutsi-, lutsepäev - ringikäivaid sanditajaid on nimetatud kord pika, kord lühikese u-ga: lutsid, lutsed, lutsiijad, lutsinad või luutsinad, luutsijad, luutsid (kord eksimisi ka lustid) (vt ka Hiiemäe 1998: 243-244). Käsikirjalisi teateid on ajavahemikus 1924-1980 Hiiu- ja Saaremaalt 29: Käinast (2), Karjast (4), Mustjalast (2), Kihelkonnast (10), Ansekülast (2), Jämajast (1), Kärlast (1), Kaarmalt (3), Pöidelt (2). Kaks Lääne-Eestist fikseeritud teadet (Hanila, Tori) näikse lähtunud Saaremaalt pärinevatelt informantidelt. Enamasti pole teadetes lutside sugu määratud: küllap eeldati, et küsitleja seda teab. Siiski on teateid, kus kas öeldakse otse või antakse kaudselt mõista (nimetades osalejate eesnimesid või võrreldakse kadridega), et tegemist on tüdrukute-naistega (Reg 2.10, 11, 12, 13, 15, 18, 21, 25, 26, 27). Mõned teated kõnelevad noortest inimestest (2.4, 23, 24, 29). Ühesainsas ja ka muidu segasevõitu tekstis (lutsid kolmekuningapäeval?) öeldakse, et lutsid olnud "mehed puha, külapoisid" (2.28). Ühe teate järgi olid lutsid meesteks riietatud naised (2.11). Paistab seega, et reeglina - vähemalt algselt - käisid lutsiks tüdrukud ja naised.

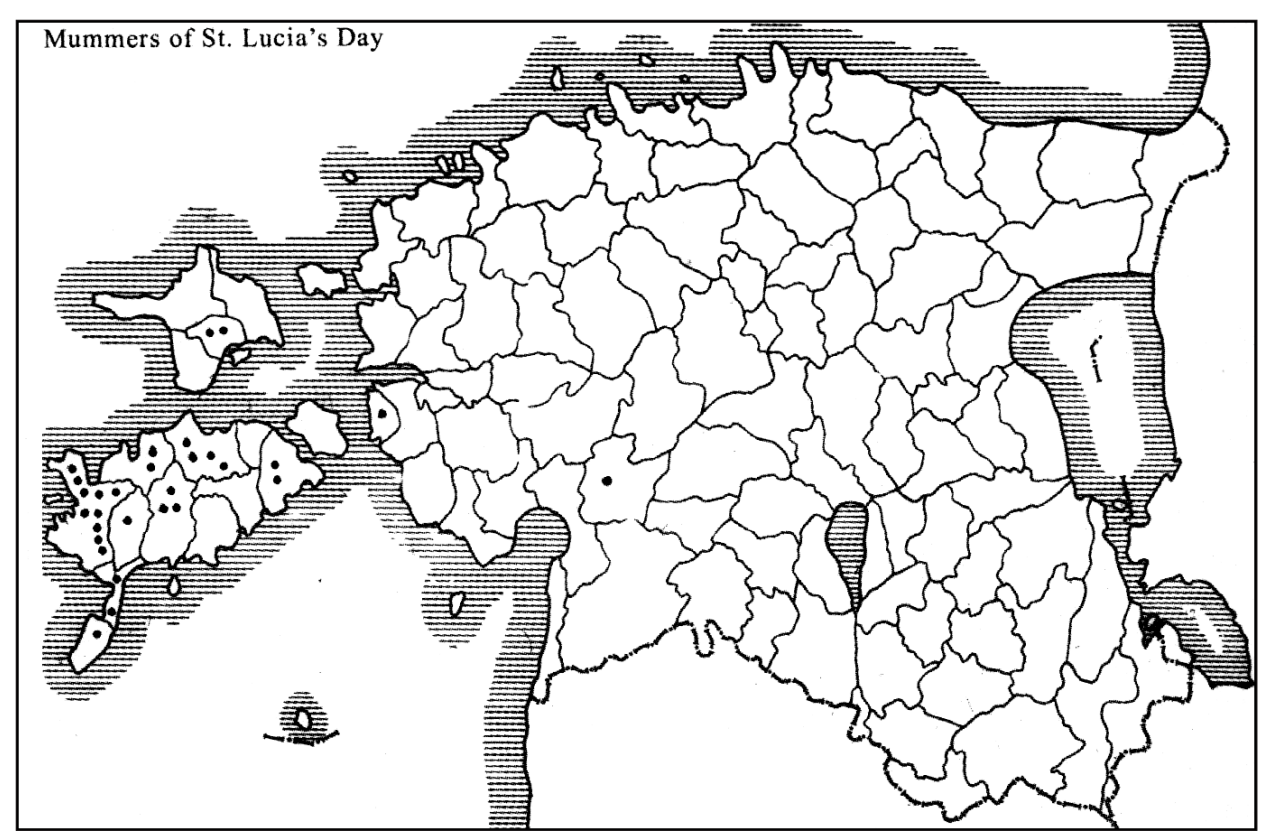

Lutsid. Ülo Tedre koostatud kaart. 
Riietuse kohta on konkreetseid andmeid vähe. Mainitakse valget riietust (kasukat) $(2.14,21,27)$, teistmoodi riides (2.4), karvast kasukat (2.8), aga öeldakse ka ükskeik mis riided olid üll (2.13). Teiselt poolt märgitakse ehitud, uhkeid riideid $(2.15,25,26)$, eriti pitside, kettide, höövlilaastudega ehitud kübaraid $(2.15,18,27)$. Ilmselt erandlik on teade, milles märgitakse, et lutsil selline suur, suur änd olnud järge (2.20). Meenutagem, et samuti Lääne-Saaremaalt pärines ka teade sabaga andresest (1.6). Võimalik, et tegu on kohaliku maskeerimiskombega. Ka on teateid, et lutsi oli maskiga (2.13), matetud palgega (2.20), marli näo ees (2.27).

Peaaegu üldine on teade, et lutsi käis luuaga $(2.2,4,6,7,8,9,11,12,14$, 19, 23, 24, 26). Kui märgitakse, et lutsi pühkis põrandat kaseokstega (2.3) või kadaka (2.25), siis viitab see tegevus selgelt luuale. Asendumine võis toimuda kas konkreetselt ringkäigul või teate edastaja mälus, kuid atribuudi funktsioon on sama. Hoopis erineva tähendusega on vitsakimp lutsi käes $(2.13,27)$, mis viitab pererahva (s.o külastatavale tervendavale vitsutamisele (vrd mardisantide tavaga).

Üksainus teade ütleb sõnaselgelt Lutsiia oli ka keind änamasti üksikult (2.10). Üksi käimisele viitavad veel teated nagu luts tuleb $(2.2,3,5,7,8,19)$. Enamasti on aga lutsidest mitmuses kõneldud, märkimata küll käijate hulka $(2.4,6,9,11,12,13,14,15,16,18,20,21,23-29)$. Ainult kahes teates on juttu lutsikskäijate n-ö juhtidest: ühes nimetatud lutsi isa (2.26), kes ei tarvitsenud olla mees, vaid oli meheriietes naine; teises aga lutsiema (või nn esikut) (2.27). Tegemist on ilmse laenuga mardi- resp. kadrisandi pärimusest. Kommete segunemine on mõistetav: tähtpäevad on ligistikku, nii kadriks kui lutsiks käimise traditsiooni kandsid tüdrukud. Vanema ja kommeterohkema kadripäeva mõju nooremale tähtpäevale on selge.

Luutsinapäevaks pidid talu sügistööd olema lõpetatud ja algas jõulude ettevalmistus (2.29). Ka lutsid olid jõulude kuulutajad: nad andsid teada, millal jõulud tulevad $(2.25,27)$. Jõuludele viitab ka kontrollimine, kas tuba on puhas (2.9) ja toa puhtaks pühkimine $(2.4,8,11,12,19,23,24,25,26)$. Sügiseste sanditamiskommete mõjule viitavad laste hirmutamine $(2.2,3,4,21)$ - seda kohtab küll paljude sanditajate puhul, ja kartus on laste loomulik reageering - ja laste loetamine $(2.13,18)$; samuti pereemalt pärimine: kas lõnga on kedratud, mitu lõngavihti on (2.8). Lutsiema või -isa esinemine on ilmselt laen kadri- või mardisantidelt $(2.26,27)$. Lutsiema õnnesoovimine pererahvale ning lutside pererahva vitsutamine (2.27) on samuti üle võetud mardi-kadrisanditamisest. Ka tantsimine $(2.13,15,18,28)$ näikse viitavat mainitud eeskujule. Seevastu möllamine ja pahanduste tegemine $(2.12,21)$ seostub teiste jõulusantidega. Üksikteade laulmisest (ilmselt on tegu uuema, siirdevormilise või riimilise lauluga) ja seltskondlikust mängust (2.29) osutab traditsiooni muutusele ja seostumisele nn külapidudega. 
Teateid on lutside kostitamisest. Neile pakuti õunu (2.12), palle (s.o käkke) ja pannileiba (2.15), pähkleid ja õlut (2.28), präänikuid, pähkleid, õunu ja õlut (2.29). Ühe teate järgi oli lutsidel kott kaasas, kuhu kohuti andeid, mis jagati viimases külastatavas peres (2.15). See on taas laen kadrisanditamiskombest.

Kombele võime leida paralleeli Rootsist. Ehkki rootsi Luciate ja eesti lutside ühisjoonteks näikse olevat ainult sugu (tüdrukud-naised) ja valge riietus, võib siiski oletada teatavat mõju või eeskuju teispoolt Läänemerd. Kalurite ja meremeestena oli lääne-saarlastel kindlasti kokkupuuteid rootslastega. Tegemist on ilmselt eeskujuga, mitte otsese kombelaenuga. Kombe vanust tuleks seostada andrusepäeva santidega ehk 19. sajandiga, (võimalik on muidugi mõnevõrra varasem päritolu). Tänapäeval näikse meie kohalik lutsiks käimine juba unustatud. Kommet püütakse elustada linnades ja otseselt Rootsi-Soome praegusest esinemisest lähtudes (kaasa arvatud „Santa Lucia“ laulmine). Kas tava juurdub, sellest puuduvad veel andmed.

\section{1.a.3. Toomapäev - 21. detsember (3)}

Toomapäevaga algasid jõulud (Hiiemäe 1998: 247-252). Jõulu ettevalmistuste hulka kuulus tare puhastamine (e musta tooma välja ajamine) ja õlle tegemi-

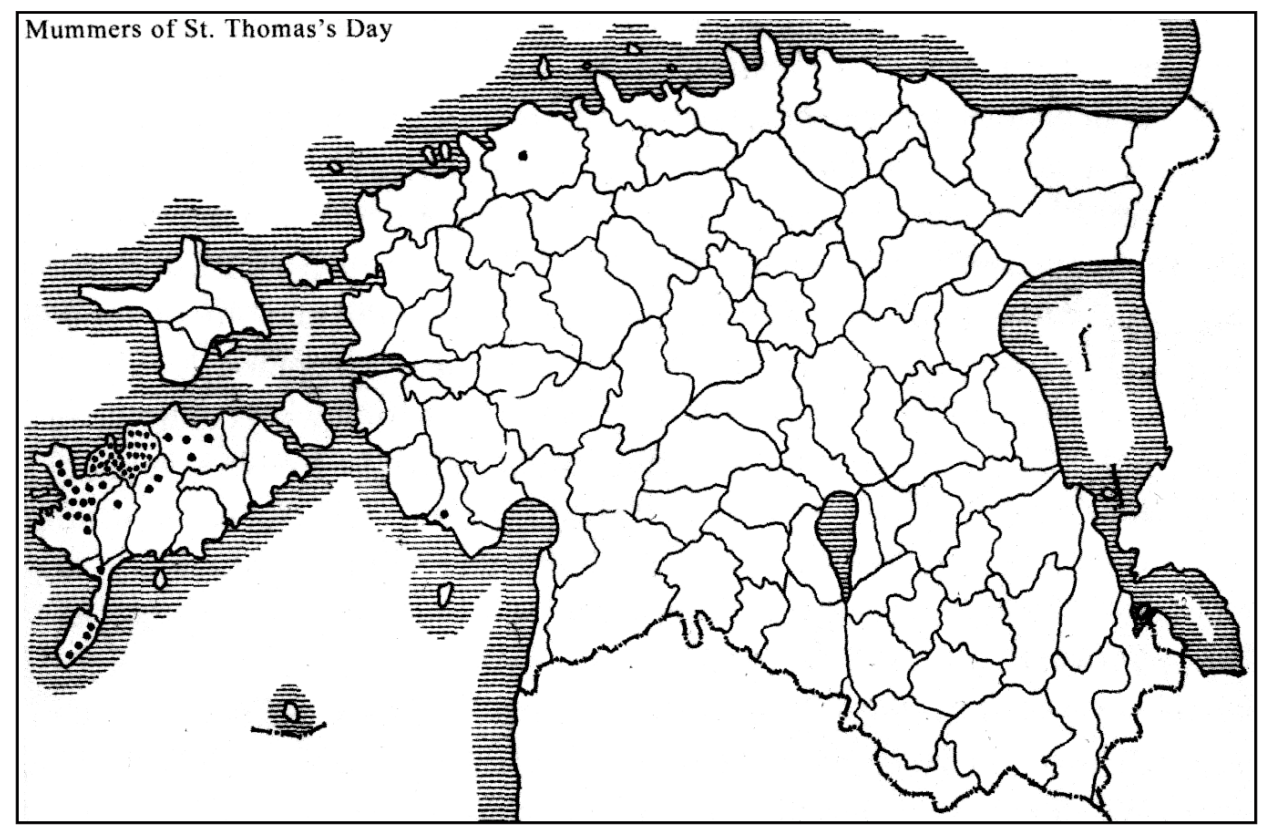

Toomad. Ülo Tedre koostatud kaart. 
ne (toomas tuleb sisse, valge müts pääs ja toob jõulud - Valge müts tähendas õllevahtu, E, StK 39, 264/5 (37) < Kihelkonna, 1926) või Toomas tuleb, toop kaenlas (Seletus: see tähendas õlle tegemist, E XI 39 (101) < Tartu-Maarja ja E 57639 (26) < Kadrina.).

Viimasega seostub ka maskeeritult külapidi käimine. Käijaid on nimetatud toomasteks, toomaks või jõulutoomaks (3.7-10, 40, 57), erandlikult mustaks toomaks (3.54). Üldiselt kõneldakse toomaks käimisest; ühe teate järgi mindi toomast vaatama (3.25). Ühtekokku on aastaist 1930-1978 57 teadet, peamiselt Saaremaalt (Keila 1, Saaremaa 1, Karja 4, Mustjala 27, Kihelkonna 13, Anseküla 1, Jämaja 1, Kärla 2, Kuressaare 2, Kaarma 2, Tõstamaa 1).

Kaks teadet väljaspool Saaremaad (3.1 ja 57) viitavad tava kunagisele suuremale tuntusele (võimalik on muidugi, et informandid olid endised saarlased). Nuudipäevaga vahetamisest kõneleb teade 3.22, mis laseb toomaks käia kolm päeva pärast jõule ja otsida (õllevaadi) punne.

Toomaks käisid valdavalt mehed $(3.1,17,18,19,27,35,36,46,47)$ või noored mehed $(3.4,10-12,19,45)$. Ühes teates öeldakse, et toomaks käisid vanad peremehed (3.43). Mõned teated märgivad noori, sool peatamata (3.2, 34). Ainult üks teade ütleb, et hulgas olnud ka noori tüdrukuid (3.39) ja üks, et toomas oli naisterahvas meeste riietes (3.8). Naiste osalemine on juhuslik (või on tegemist informandi meenutusveaga). Enamik teateid kõneleb Toomastest, millest järeldub, et käidi hulgakesi (ühes teates lausa öeldakse, et olid 10-11 meest (3.17). Seevastu kolm teadet kinnitavad, et käis üks mees $(3.3,5,6)$ ja ühes öeldakse, et käidi küll mitmekesi, kuid kõik pole olnud toomad, vaid saatjad (3.44). Sellega seostub unikaalne teade, et käisid Tooma-nimelised ja taludes, kus teati olevat Tooma-nimelisi (3.14).

Järeldus suhteliselt ühenäolisest pärimusest on üsnagi selge: toomaks käisid mehed, algselt vanemad; hiljem - kui tava rituaalsus asendus mängulisusega üha suuremal määral nooremad. Naised tulevad sekka (kui tulevad ja tegu pole meenutuse segiminekuga) juba tava lõpufaasis.

Maskeeringu suhtes eksisteerivad samuti kahesugused, mõneti vastandlikud teated. Enamik teateid rõhutab valget riietust (märgitakse eraldi valget särki ja valgeid pükse $(3.2,4,9,11,14-16,19,21,23,27,29-31,33)$. Võimalik, et see haakub nimepäevatraditsiooniga, mis oli Eestiski üsna tuntud, ent paraku vähe uuritud. Vastavaid andmeid leidub muidugi Eesti rahvakalendri köidetes (vrd Talve 1966). Ühes teates märgitakse valget mütsi (3.37). Siin on kohane osutada vanasõnale “Jõulutoomas tuleb, valge müts peas" (EV 1980: 516, nr 2740). Kahes teates märgitakse punast vööd (3.23 ja 31). Ühes teates olnud käijatel paberist nägu ees, s.o paberist mask (3.2), teises lihtsalt mainitakse, et olid maskeeritud (3.36), täpsustamata kas mõeldakse maski või riietust. Kahes teates öeldakse: suured näud ja abemed ees $(3.42,46)$, mis viitab maskile. Veel on teateid, 
mis osutavad segunemisele martide kostüümile: koduselt riides, pealtnäha vanad-habemikud (3.41), pahupidi kasukas seljas (3.45), seljas vanad riided (3.49), olid teistmoodi riides, suure habemega (3.40). Viimase teate puhul võib oletada segunemist nn jõuluvana-pärimusega (seda nõukogude okupatsiooniaastail muidugi välditi teemaks võtmast). Teistest erinevad kolm teadet mille järgi käijatel olud tahmaga määritud näod (3.1 ja 35) või olid ennast mustaks määrinud (3.54). Eeldatavasti seostuvad need "Mustad Toomad" toomapäevase suurpuhastusega, mis hõlmas ka kerise puistamist (s.o kerisekivide tahmast puhastamist ja pragunenud kivide asendamist tervetega) ja lõppes musta tooma või tahmatooma sümboolse või ka materiaalse välja viimisega.

Puhastamine kui Tahma-Tooma sümboolne välja ajamine on tuntud Mandri-Eestis. Materiaalset Tahma-Toomast (õlg- või kaltsunukku) on enamasti kantud pärast jõule (nääride aegu).

Tooma ühele algsetest funktsioonidest viitab kaasaskantav õllelähker, millest pererahvast kostitati, kes pidi siis tühjaksjoodud lähkri uuesti täitma (3.36, 41, 42, 43, 51).

Maskeeringu hulka kuulus toobripuu või selleks nimetatud kaigas käes (3.3, 5, 6, 9, 14-21, 23, 26, 28, 30, 32, 33, 39, 42-46, 52, 53, 55). Ühe teate järgi olnud punase lõngaga märgid peale siutud, kust saadik ükski pää akkas - jõulud, nääripää, kolmekuninga pää ja kü̈̈nlapää (3.9). See seostub pärimusega, et toomad teatavad jõuludest kolme päeva pärast $(3.7,12,16)$ või soovivad häid jõule (3.16). Toobripuuga löödud tantsimise ajal takti $(3.16,37,41,46)$ või löödud muidu vastu maad (3.19).

Valminud õlle viimist sugulastele ja ka naabritele ehk nn laotise viimist tuntakse üle maa. Viiakse kannuga, viija saab tänuks tühja kannu leivanuki (ka sukad või sokid või paelad). Viiakse toomapäevast jõululaupäevani. Seda on nimetatud ka toomast tooma (3.43). Nimelt oligi toomaks käimise peamine eesmärk vaatamine, kas õlu on juba valmis $(3.33,38)$ ehk toomast vaatamas käimine (3.25) ja õlle proovimine (3.3, 4, 10-12, 14, 21-24, 28, 30, 34, 45, 46, 48, $52,54,56)$. Vaadates tava pererahva poolt, on loomulik, et sedastatakse õllega kostitamist $(3.7,15,16,18-20,29,37,41,44)$. Siia kuulub ka teade:

Sel päeval läksid mehed... 1903. aasta talvel tahmase näuga kõrtsi, Toomast valgeks jooma (3.1).

Teade on Keilast, a. 1943. Kui informandi mälu ei peta, on kõrtsi jooma minek üsnagi erandlik, tegelikult ainukordne ja ilmselt mitterituaalne käik. On teateid, mille järgi on toomapäeva tavadega segunenud martide pärimus. Aga mõeldav on ka, et informandi mälu petab - on ju praeguseks enamik sanditamiskombeist kadunud; see, mis kõige kauem püsis - mardi-kadrisanditamine, võis mõjutada analoogilisi tavasid usutletava meenutustes. Niisiis arvestagem 
võimalust, et tavade segunemise asemel on tegu segunemisega mälus või meenutustes.

Nii kohtame teateid tooma laulmisest (3.10, 19, 29), tantsimisest (3.16, 37, 41, 46), kontrollimisest, kas käsitööd on tehtud (kas on lõngavihti kaela visata) (3.35), mis kõik haakuvad pigem mardisanditamisega. Pruudiõnne soovimine (3.29), õnnesoovimine uueks aastaks (3.43) ja pähklite norimine (3.34) viitab nääripoistele. Keerdküsimuste asetamine (3.42) ja nalja tegemine (3.44) sobib paljude sanditamistega ega ole vastuolus ka toomaks käimisega.

Tava on tänapäeval hääbunud. Mäletatakse, et Enne sõda ikka kadusid ee... eesti ajal oli küll veel (3.19); Umbes 20 aastat tagasi /s.o 1938/, kui käidi veel... (3.36), Toomad käisid umbes 50 aastat tagasi (s.o 1908) (3.41). Toomad keisid veel eesti ajal, aga siis juba haksid vähemaks jääma (3.44). Arvestades tava säilimist eakate inimeste meenutusena, peab imeks panema pärimuse stabiilsust. Sellest võib järeldada, et komme oli informantide nooruses üldiselt tuttav ja mõjuavaldav.

Toomas on viimane jõulude saabumist ennustav sanditaja. Edasi tulevad juba jõulusandid sõna kitsamas tähenduses. Kõik eelnimetatud jõule kuulutavad sanditajad olid tuntud Lääne-Eesti saartel, peamiselt Saaremaal ja enamasti selle lääneosas. Lahtiseks jääb, kas tava tuletub populaarsest kujundkõnest (Andres ahjuhargiga, Lutsi luuaga, Toomas toobripuuga) või vastupidi - ütlus tavast. Ütlus on küll samuti saaremaaline. Usutavasti ei ole tava eriti vana. Nimitegelased on kõik n-ö maised, miski ei seosta neid nimipühakutega - ei välimus, ei käitumine. Seega pole põhjust seostada tava katolitsismiga. Usutavasti on tava palju hilisem, tekkinud mardi- ja kadrisantide eeskujul, eesmärgiga rõhutada lähenevate jõulude olulisust. Esialgu jääb vastamata küsimus, miks keskendub see komme just Lääne-Saaremaale. Küll peab rõhutama, et jõule kuulutavad sanditajad on kadunud varem kui jõulusanditajad (viimastest on mõned tuntud veel tänapäevalgi).

Jõulupärimuse järgi oli jõululaupäev puhtalt perekeskne. Kinke toov jõuluvanagi - suhteliselt hiline, alles 20. sajandil ajapikku leviv - esines algselt enne (või pärast) jõule koolides või rahvamajades korraldatud jõulupuudel. Kodudes olid märgiks jõuluvana käimisest jäänud kingitused. 


\section{1.b Jõuluperiood}

1.b.1. Jõuluvana/näärivana (nõukogude okupatsiooni aastail)

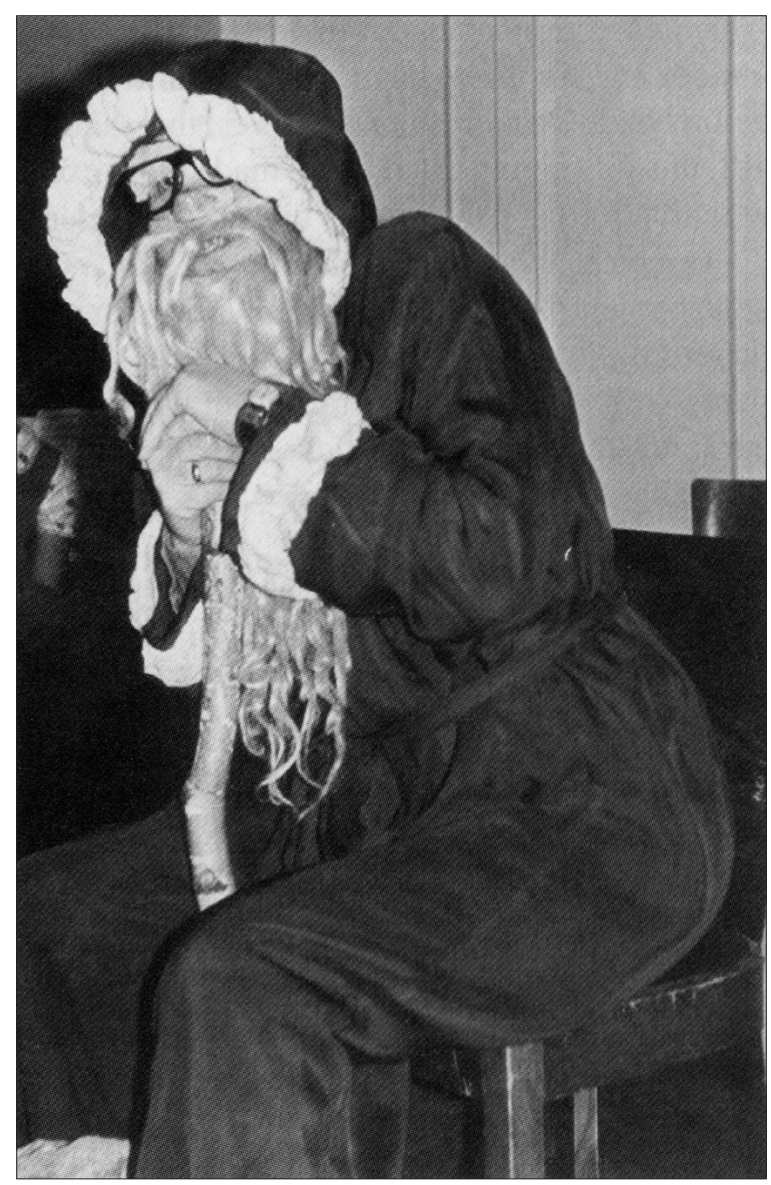

Näärivana Eesti Kirjandusmuuseumis 1978. Foto Hallik. Eesti Rahvaluule Arhiivi fotokogu.

Jõuluvana on rahvusvaheline (või kirjanduslik) tegelaskuju. Meil sai ta tuntuks nimelt avalik-ühiskondlike, ka kommertslike ürituste kaudu. Jõuluvana maskeering oli rangelt ühesugune: punane, valgete ääristega mantel, peas punane valge randiga lodumüts (ka tuttmüts), rinnuni ulatuv valge habe, seljas kingikott, vöö vahel vitsakimp.

Jõuluvana etendas pere isa või vanaisa (mõnikord paluti jõuluvanaks ka hea sõber või sugulane - aga seda juba hiljem). Okupatsiooniaastate viimastel 
kümnenditel oli võimalik tellida n.ö. professionaalset jõuluvana, s.o näärivana. Seda võimalust kasutati eelkõige asutuste nääripeo korraldamisel. Jõuluvana esinemisse kuulus alati pärimine: "Kas siin häid lapsi ka on?” Jaatava vastuse puhul kutsus jõuluvana nimeliselt lapsed (resp. kingituste saajad, peol osalejad) ette, laskis kas salmi lugeda või mõnd muud oskust (ettevalmistatud esitust) näidata. Järgnes kiitmine ja kingituste üleandmine. Viimast põnevustati kotist otsimise ja porisemisega "Kuhu ta nüüd jäigi!"

Nagu öeldud on jõuluvana kuju meil suhteliselt hiline. Tema levimisele on kaasa aidanud lastekirjandus ühelt poolt, teiselt poolt suured kaubamajad. Viimaste aknareklaami hulka kuulus kindlasti ka jõuluvana papjemašeest kuju vastava atribuutikaga: (kelk kingikotiga, kepp käes etc). Nõukamad ja jõukamad lasksid elavatel jõuluvanadel klientide seas liikuda reklaamimaks jõulukaupu. Mõistagi sai jõuluvana tuntuks kõigepealt linnades, maale - küladesse - ta enne nõukogude okupatsiooni igale poole ei jõudnudki. Paradoksaalselt on just nõukogude võim oma standartsusega, kuhu kuulus ka nääripidu näärivanaga, juurutanud küladeski (s.o kolhooside kaudu) nääri- resp. jõuluvana tegemist. See ei ole mingil moel lähtunud eesti pärimustest, vaid tervenisti laenuline, isegi mitte laenatud, vaid väljast n-ö kingitud, koguni peale surutud (või kaela määritud) tava. Selle sisu, n-ö ideoloogia on meie jõulupärimusele võõras. Jõuluvana levikule aitas kaasa ühelt poolt range stereotüüpsus, teiselt poolt lastele suunatus. Kuna lapsi oli reeglina igas peres, siis mõistagi püüti jõuluvana etendada samuti igas peres.

Kuigi jõuluvana tuntakse praktiliselt üle kogu maa, on pärimusteateid selle kohta laekunud suhteliselt vähe. Ilmselt pole kogujate eesmärgiks olnudki spetsiaalselt jälgida jõuluvana-pärimust, sestap on vastavad teated üsna juhuslikud ega anna adekvaatset pilti kombe tegelikust ulatusest. Arvestada tuleb sedagi, et okupatsiooniaastail olid nii jõulud kui jõuluvana lausa tabu-teema, aga näärivana kui n-ö ametliku ideoloogia poolt peale surutud, ei pälvinud "vana" pärimust jahtivate kogujate tähelepanu. Arusaadavalt oli see ka vastupanu või vähemalt distantseerumine puna-ideoloogiast.

Jõuluõhtu oli seega perekeskne, mida alles 20. sajandil segas jõuluvana. 19. sajandi keskelt pärinevad teated tunnistavad ka esimese püha päevaks, millal külas ei käidud. Tõsi, on ka erandeid. Seevastu teisest pühast algab külaskäimine, mis hõlmab ka rituaal-tseremoniaalseid külaskäike - maskeeritult või ilma.

Ühtsete jõulude seas kerkib kolm n-ö harja või tipppunkti: päris-jõulud, näärid ja kolmekuningapäev (või nuudipäev) (Hiiemäe 1998: 253). Sanditajad vastavatel päevadel erinevad küll nimetuse poolest, kuid mitte oma maskeeringult, käitumiselt ja ka funktsioonilt. Sestap vaatlen järgnevalt n-ö ühetüübilisi sanditajaid koos, mitte tähtpäeviti. 


\section{1.b.2. Jõulupoisid (4)}

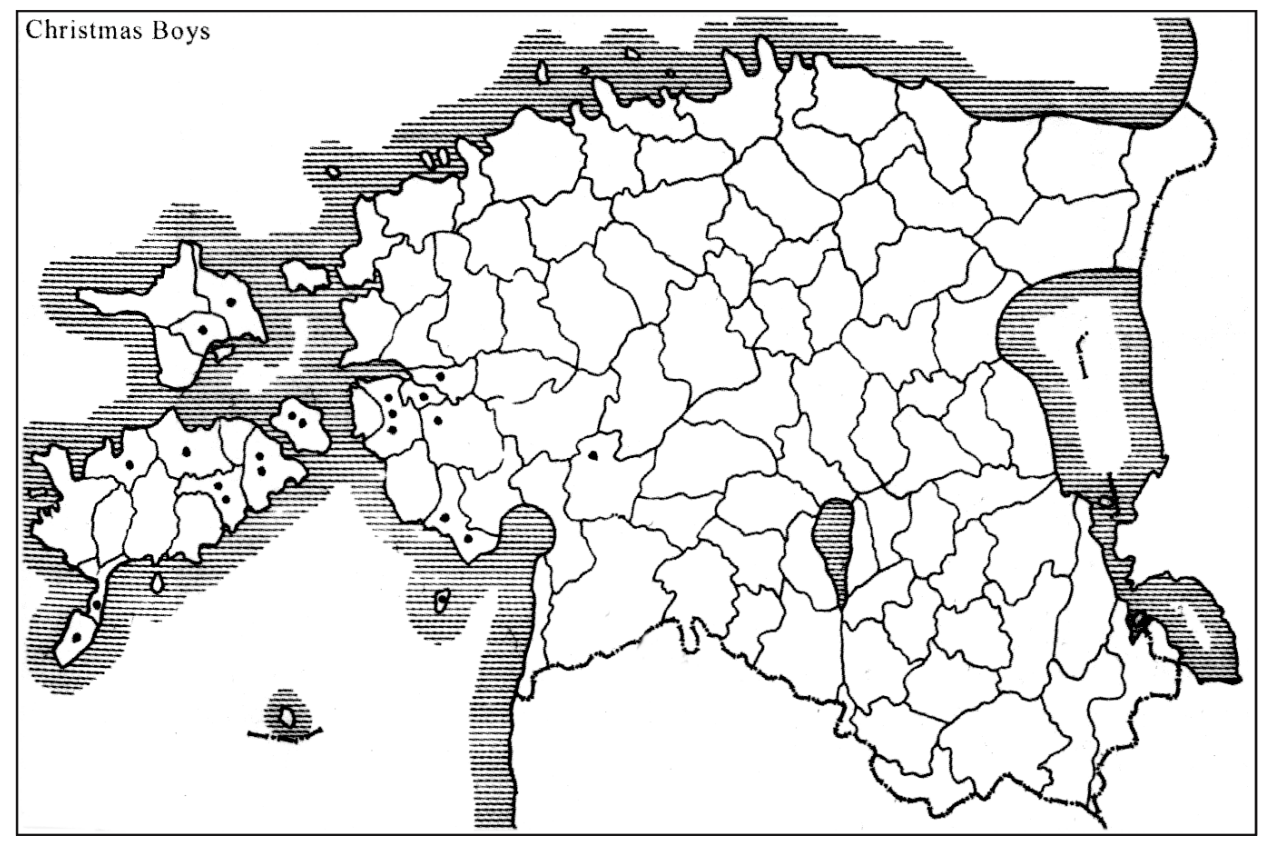

Jõulupoisid. Ülo Tedre koostatud kaart.

Esimesena nimetagem jõulupoisse, kes käisid ringi jõululaupäeval (4.15, 24), jõululaupäeva ja esimese püha õhtul (4.14), enamasti aga esimese püha hommikul (4.1, 4, 6, 10, 13, 16, 17, 21, 23 ja 25) või ebamääraselt jõuluajal, ka pühade vahel $(4.2,3,5,11,12,18-20,22)$. Neist on aastail 1888-1977 kokku 25 teadet, eranditult Lääne-Eestist (kaasaarvatud saared). Neid nimetati üldiselt jõulupoisteks $(4.1,4,5,8,9,15,16,18,21)$ võijõulupoisikesteks (4.13), ka pühapoisteks (4.6) või pühadepoisiks (4.7). Mõnel juhul on kasutatud vaheldumisi nimetust jõulu ja uue aasta poisid $(4.19,22)$ või nääripoisid (4.24). Enamasti märgitakse, et käijad olid poisid $(4.2-5,11,12,14,24)$ või rõhutatakse, et noored poisid $(4.8,21)$ või koguni pisikesed poisid (4.15) resp. väikesed poisid (4.17). Ühe teate järgi olnud käijad 14-15 aastased (4.13). Aga on öeldud ka, et noormehed $(4.1,9)$ või noored (4.10). Ühe teate järgi käinud varem noored mehed (4.16), aga nüüd - s.o 19. sajandi 80-ndad aastad - pisikesed poisid. Ainult kahes teates mainitakse mehi (4.20 ja 25).

Maskeerimisest või eririietusest juttu ei ole. Atribuutidest on ainult kaks teadet Karjast: 
Jõulude aegu käinud poisid külas, õlenuudid käes ja andsid pererahvale peksa ise öeldes: terveks, teravaks, terveks, teravaks! (4.12)

ja Pöidest:

Erilise lugupidamise sees olid nn jõulupoisid, need käisid salkade viisi talust tallu, külast külla ja mõnikord isegi vallast valda. Tantsiti, joodi ja söödi. Tülid ja kaklemised olid tundmata. Ka nn pühade vahel võis igal ajal jõulupoisse oodata, kes - lõõtsapillid kaenlas ja õlekubud seljas - pererahva hariliku töö seisma panid ja tantsu lahti päästsid (4.18).

Siin on tegemist tavade segunemisega (või informandi mälestuste segunemisega): õlest nuut viitab nuudipäeval ringikäimisele (nuutidega pühitud õllevaadi punne kokku - see metafoor tähendab jõuluõlle lõpetamist), vitsutamine koos

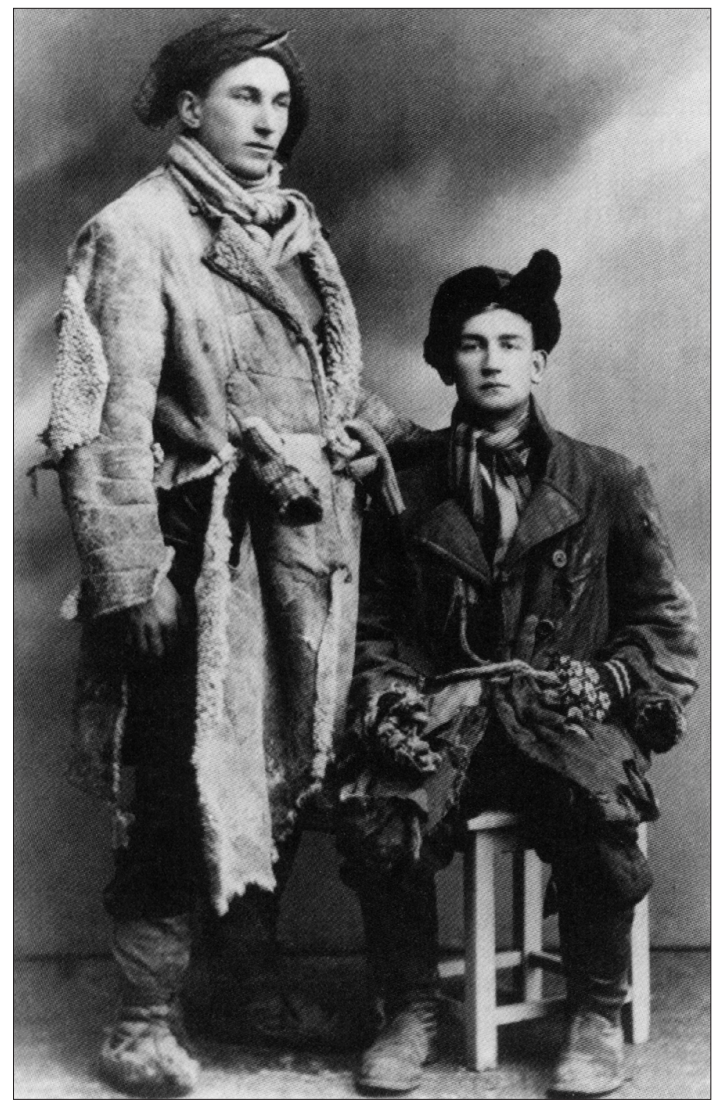

Kaks kehvalt riietatud jõulupoissi Saarde kihelkonnast Tali asundusest, 1930. Eesti Rahvaluule Arhiivi fotokogu. 
sooviga "terveks" aga mardisantidele. Õlekubu aga viitab tavale tuua õled tarre "kolmeks ööks ja kaheks päevaks", kusjuures õlgede tooja ja tares olija dialoogis samastati õlekubu jõuludega (Hiiemäe 1998: 256 jj). Õlekoo tassimine viitaks seega jõulude algusele või kestmisele. Teade on küll unikaalne, kuid ei tarvitse olla väljamõeldis või ununemise tagajärg. Jõulupoiste käimise eesmärgist on teateid vähe ja need osutavad maagilisrituaalse ja lõbustusliku funktsiooni segunemisele. Nii märgitakse, et jõulupoisid soovisid häid pühi $(4.9,13)$, õnne (4.25), kõike head: piima, võid, vasikaid (4.15, vrd nääripoiste sooviga): mitmes teates märgitakse jõulupoiste laulmist - ukse või akna taga $(4.4,5,8,14,19)$. Teisalt on teateid, et jõulupoisid tantsisid, tegid nalja $(4.11,18,22)$, neil olnud pill (lõõts) kaasas $(4.11,17,18)$. Uuemad teated ütlevad lausa: See oli nendel /s.o jõulupoistel/ joomaaeg, ega nad muul ajal joonud (4.3).

Sellega jõuame kostitamise juurde. Vanemad teated kõnelevad söötmisest, jõululeiva ja -vorstiga kostitamisest $(4.5,7,25)$, tüdrukute poolt pähklite andmisest (4.8, 9, 13, 20), ka kinnaste-sokkide kaelariputamisest (4.7, 10), mis tavaliselt seostub nn sokuga. On ka mainitud kõiksugu andeid (4.6) või tingimust, et midagi pidi kinkima (4.23). Uuemad teated aga rõhutavad õllega kostitamist $(4.8,11,17,20)$. Käidi hulgi, ainult mõni teade $(4.14,23,25)$ ütleb, et käidi üksi või paariti.

Jääb veel küsida, millal tava kadus. 19-ndast sajandist pärinevad teated $(4.10,16,17)$ räägivad tavast olevikus kui eksisteerivast. 20-ndast sajandist pärinevad teated on aga kõik minevikulised. Ühes teates (4.11) antakse piir: tava oli tuntud Esimese maailmasõjani. Jõulupoisse on täielkult asendanud nääripoisid, mida kohati tuntakse ka praegu.

\section{1.b.3. Nääripoisid (5)}

Nääripoisid taotlesid olla uuel aastal esimesed õnnesoovijad - külalised. Taotluse aluseks olid usundiline kujutelm: kui esimene külaline on naissoost, siis toob see õnnetust või rikub maja-õnne, mida vanem naine - seda suurem häda ja õnnetus. Sestap käisidki poisid või noormehed külapidi õnne soovimas ja toomas (Hiiemäe 1998: 295/6). Tavast on kasutada 146 teadet aastaist 1872-1986. Tava on küll tuntud üle maa, kuid eriti populaarne on ta Lääne-Eestis, eeskätt Saaremaal.

Teateid on küll rohkesti, kuid enamasti on nad üldsõnalised. Enamik teateid märgib, et ringikäivaid onnitlejaid nimetati nääripoisteks (5.1, 2, 14, 22, 23, 25, 28, 29, 3437, 39-42, 44-47, 49-56, 58-60, 62, 63, 65-67, 69-71, 74-77, 81, 83-86, 89, 90, 92, 93, 95, 97, 98, 100, 102-106, 108-119, 124, 126, 132, 137, 146) või tautoloogiliselt uue aasta poisteks (5.24, 26, 27, 30, 31-33, 48, 72, 78, 88, 101, 120-123, 125, 130, 134). Veel on levinud nimetus Nääri-Jaak (5.11, 38, 
138, 141-143, 145). Juhuslik tunnukse nimetus uue aasta sõbrad (5.15). Kord on samastatud uue aasta poisse näärisokkudega (5.33). Nimetus näärimees (5.38) on ilmselt ülekanne ofitsiaalsest näärivanast.

Tavaliselt märgitakse käimist salga või kambana, vähemalt kõneldakse tekstis nääripoistest mitmuses $(5.1,3,4,6-8,10,12-17,19-36,39-46,48-53$, 55, 57-67, 70-93, 95, 97, 99, 100, 102-115, 117, 118, 120-122, 125, 127, 131, 135-137, 140, 144, 146). Ent on rida teateid, mis märgivad käimist üksinda (või kahe-kolmekaupa) $(5.2,3,18,37,38,47,54,56,68,69,94,98,101,119$, 123, 124, 126, 132, 134, 138, 141-143, 145). Regionaalset eelistust pole võimalik tuvastada.

Üldiselt on märgitud käimist nääripäeval. Ainult mõned teated täpsustavad, et nääripoisiks käidi nääriööl pärast keskööd, s.o uue päeva algusel $(5.7,15$, $43,46,49,63,66,70,71,73,74,80,81,102,108,109,123,128,134,135)$. On veelgi täpsustatud, et käidi kella ühe ajal (5.58). Üks unikaalne teade ütleb, et enne kella nelja ei mindud - enne ei lastud sisse (5.68). Rohkesti on teateid, et käidi nääripäeva hommikul, mõnikord täpsustusega - hommikul vara (5.8, $13,17,19,20,21,35-37,41,55-57,64,72,78,83,85,103,114,124,126,130$, 131, 136-138, 140-142, 145). Sageli nenditakse, et käidi öö läbi (5.6, 34, 38-40, $42,51,60,61,79,86,111,112)$. Arvestades ühelt poolt teadete lihtsustavat

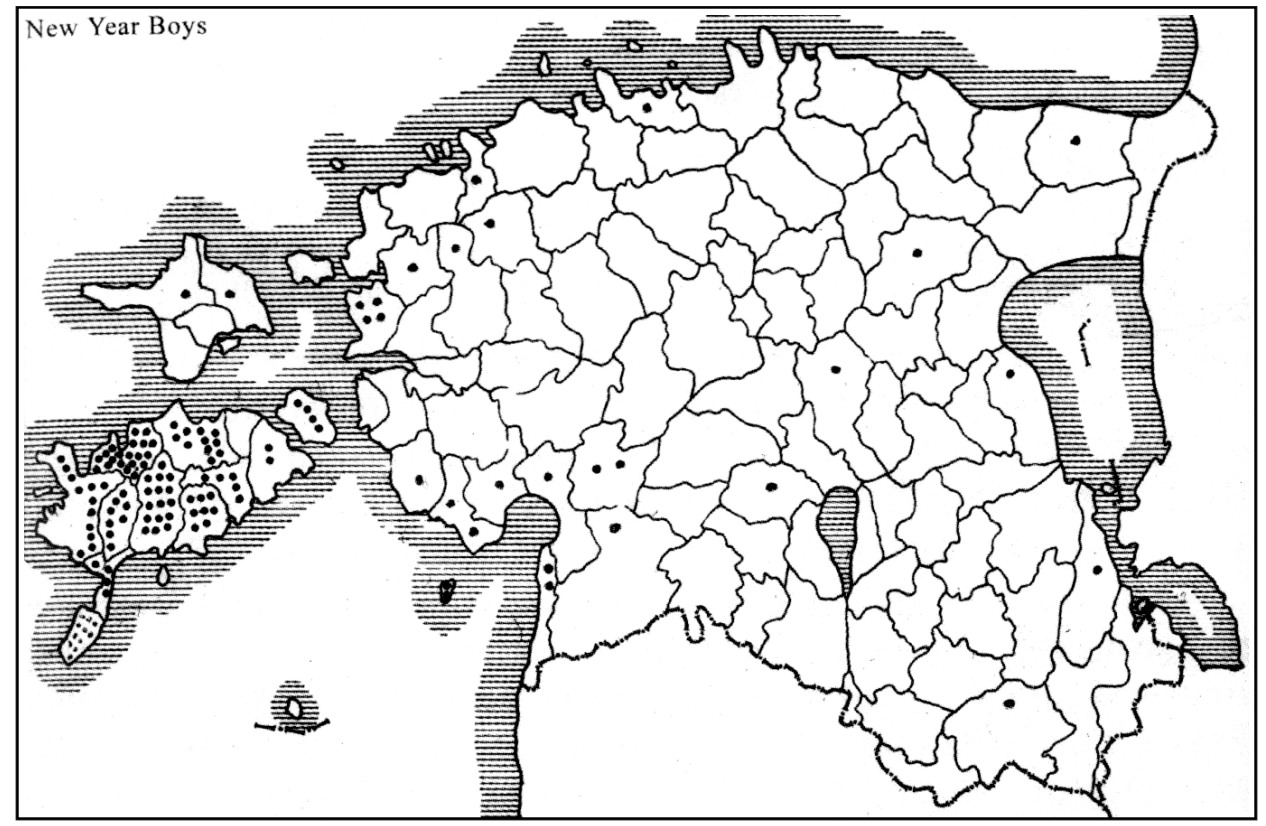

Nääripoisid. Ülo Tedre koostatud kaart. 
üldsõnalisust, teiselt poolt mõistete hommik, päev, öö käibekeelset piiritlematust, võib olla kindel, et nääripoisiks käimine algas nääride saabumisega, s.o, öösel, kui kell oli 12 (s.o 24). On kohalik iseärasus, kui käimine algas kell üks või kell neli. Kuna käidi läbi oma küla pered ja naaberküladki, siis venis käimine tõesti nääripäevani välja.

On omaette küsimus, kes olid käijad. Nad pidid olema meessoost. Põhjendus on ühene: "Kui uue aasta hommikul esimesena naisterahvas majasse tuleb viib uue aasta õnne ära. Abi selle vastu: naisterahvale tulevad ukse peal püksid kaela visata. Kui meesterahvas tuleb, on hää õnn uuel aastal" (5.130; vt ka 4, $14,19,75,91,101,135)$. Kuid teated on käijate ealisuse osas erinevad. Ühed ütlevad, et käisid lapsed $(5.20,115)$, poisikesed $(5.3,13,17,126)$, pisikesed poisid $(5.80,124)$, väikesed poisid $(5.91,99)$ või lihtsalt poisid $(5.4,57,61,67$, 127, 129, 135, 136) resp. naabripoisid (5.82). Teised kinnitavad, et nääripoisid olid noored (5.12), noormehed (5.8, 19, 26, 30, 64, 68, 73, 107, 140, 144) või nooremad tragimad mehed (5.43). Kolmandad räägivad meesterahvast $(5.9,138)$ või meestest $(5.6,10,16,21,126,128,135)$. On nimetatud ka meest "kes väga vana ei ole ega väga noor" (5.18) ja koguni vanameest (5.141). Mälestusedki on vastuolulised. Aastal 1960 teatatakse Muhus ja Kaarmas:

Kui ma noor olin, nii käisid nääride aegas õnne soovimas väiksed poisid... Nü̈̈d iljem ajal on käinud suuremad, noored mehed (5.20, 99),

paar aastat varem aga Pühas:

Nääripäeval käivad nääripoisid, uie aasta õnne soovijad... Suured poisid, noored mehed käisid. Nü̈̈d käivad pisised poisid (5.113).

Arvestades kombetäitjate nimetust - nääripoisid - ja kujutelma, et õnnesoov on seda mõjukam mida noorem on meessoost õnnitleja, võib küll algseks pidada poisikestest õnnitlejaid.

Õigupoolest on selline kujutelm pahupidipöörang: usuti nimelt, et aasta on seda õnnetum, mida vanem on esimene naisterahvast külaline. Tuletus kujutelmast on seega vastupidine: mida noorem meessoost külaline, seda parem. Kujutelm hõlmas ka esimest vastutulejat uuel aastal (või kalale resp. jahile minnes).

On väheseid teateid, kus nääripoisid on kas samastatud näärisokuga või tehtud soku saatjaks $(5.41,48,49,66,75,95,120,122)$. Samas on rõhutatud: Esiti käisid ikka sokud; uieaastapoisid-see uiem komme (5.33) ja Nääripäeval käisid nääripoisid. Lapsed käisid. See pole nii vana komme olnd (5.115).

Nääripoisid reeglina ei olnud kostümeeritud-maskeeritud. Ainult ühes teates (5.134) mainitakse näokatet. Õlgedest punutud mütsi nimetavad viis teadet $(5.1,74,108,110,112)$, õlgedest kuube või rüüd kolm teadet $(5.2,7,110)$. Veel 
on märgitud pahupidi kasukat (õlgedest vööga) $(5.5,112)$ ja valget riietust (lutside mõju) (5.39). Krooniks nimetatud peakatte all (5.125) tuleb vististi mõista õlgedest valmistatud mitme keerusarvega peakatet (5.112). Rohkem on teateid õlest põimitud nuutide kohta (vrd nuudid), mida nääripoisid kasutasid pererahva, eriti magajate, virgaks ja erguks löömiseks $(5.23,31,34,47,83$, 85, 87, 88, 89, 95, 96, 98, 100, 102, 103, 108, 109, 112). On kaudseid teateid, et käidi võidu, sest andeid said ainult esimesed (resp. esimene) (5.35, 36, 42, 45, 49, 54, 89, 119). Hilisematele öeldud: Käidud juba. Ja need pidid söömatajoomata lahkuma (5.19).

Mardisantidele iseloomulikku tuppa laskmisega kaasnevat dialoogi kohtame nääripoistel ainult ühel korral:

Nääride laupa õhtu tuli kedagid ukse taha ning koputas ja küsis luba sisse tulla. Seest aga küsiti: kes ta on. Kui väljast tuli vastus, et ta on uusaasta, siis küsiti veel, mida uusaasta toob, kas head või santi, mitu vasikat, mitmed kaksikud talled, mitu seapõrsast jne. Kui ukse taga olija kõik küsimused oli vastand, siis lasti ta sisse ning anti talle õlut juua, et vili kasvaks, liha süea, et lihapuudus käde ei tuleks, samuti piima, võid jne. Siis käis "uusaasta” kõik ruumid läbi ning läks siis edasi teise perese. (5.94).

See on improvisatsioonilis-mänguline edasi arendus nääripoiste külastusest, mis ju algab head uut aastat $(5.2,5-8,12,15-18,20,21,26,27,29,35,86,124$, $125,129,134,144)$ või õnne soovimisest $(5.19,24,25,36,38,52,57,58,60$, $64,68,73,76,77,99,104,113,114,133,135-138,140,142,143,145)$. Eeskätt Saaremaal seostub aga õnnesoovimisega loitsuline õnnitlus taluperele; näiteks:

Tere oomikut, nääriomikust, ead õnne uie aasta vasta!

Tüdrukud mehele, kanad munele, obestel iirud varsad, (Iirud - mõeldud hiirekarva, halli)

lammastel laugid talled, (Laugud - peaks tähendama musta lammast valge otsmikuga - valge laiguga otsmikul)

lehmadel leedid vassikad, (Leedid - hallkollakad (võik))

seale seitse põrsast!

Vanad tüdrukud vasta põhituult! (5.98).

Esituse käigus see loitsuline õnnitlus mõistagi varieerub nii sõnastuses kui ka üksiksoovide arvus $(5.86,88,102,110,120)$. Kõige lühem näikse olevat:

Ead uut aastat!

Tüdrukud mehele, kanad munele! (5.100, 122). 
Antud soovis rõhutatakse loomade välimust, ent käibel on olnud ka soovõnnitlus, milles rõhk on arvukusel:

Tere omikust, nääri!

Seale seitse põrsast,

kanale kaheksa poega,

lehmale vasiktall! (5.37).

Seegi soov varieerub nii sõnastuse kui ulatuse poolest. Soov tütred-tüdrukud mehele, kanad munele näikse esinevat peaaegu kõigis soovõnnitlustes. Teinegi loitsuline õnnitlus ulatub lühisoovist - näiteks Lammastel kaksikud talled, seale kaksteist põrsast! (5.48, ka 39 ja 43, 120) pikkade soovideni (5.26, 31, 33, 37, $40,49,83,113,121,139)$, milles puhuti segunevad esimese ja teise soovõnnitluse motiivid. Sisult samasugused, kuid sõnastuselt tugevamini varieeruvad soovõnnitlused:

Tütred mehele, kanad munele,

head loomaõnne ja põllukasu

ning kõige rohkem nisu!

Hobusele laugik varss,

lehmale leedik vasikas,

lammastele kaksikud talled! (5.123, ka 97).

Esiletõstmist väärivad kaks soovi Mustjalast, milles erandlikult mainitakse ka poisse:

Tere, ead uut aastat!

Tüdrukud mehele,

kanad munele ja

poisid kosja ja

lammastele kaksikud talled! (5.36).

Teises soovis saadetakse poisid küll karja (5.39), kuid see võib olla nii informandi kui üleskirjutaja eksimus. Erandlik on ka Jõelähtme soov:

Tere teile! Head uut aastat;

rahu, tervist, head elu,

rikkaks saada ja vanaks elada! (5.3)

ning üks soov Karjast:

Ead uut aastat!

Vilja kasvu, looma kasvu,

noortele ruudiks saamist! (5.25). 
19. sajandil kirjapandud soovõnnitlus on hilisematega võrreldes unikaalsem ja metafoorsem:

Jumal andku hääd õnne uue aasta sees!

Sigigu kanapojuksed ja karjaluksed!

Üks mingu õuest, üheksa tulgu õue!

Tütred mehele, kanad munele!

Pere-emmele ja -taadile valge peaga poigi!

Vanadele raudlasna ja kergukella! (5.91).

Karujaluksed tähendasid siin ilmselt kõiki loomi (vastanduseks kanapojuksed). Õuest minema võib tähendada niihästi abiellumist perest välja kui ka suremist, ent mõeldav on ka palgalise lahkumine. Õue tulemine võib tähendada nii peresse abiellumist kui ka sünnitamist. (Vaevalt tööjõu palkamist.) Raudlasna (s.o labida) ja kergukella soovimine viitab ilmselgelt matustele. Selleski soovis on juba vormel tütred mehele, kanad munele, mis läbib kõiki soovõnnitlusi läbi sajandi. Ühest viiskümmend aastat hiljem kirjapandud soovõnnitlusest leiame eelmisest pärinevaid soove:

Tere hommikut! Hääd uue aasta õnne!

Tüdrukud mehele, kanad munele,

tuhat tutikat, sada sarvikut, viiskümmend villhända, kuuskümmend komberjalga!

Sigigu siuksed, kasugu karujaluksed!

Üks õuest mingu, üheksa tulgu! (5.112).

Siin on kasutatud ka rahvalauludest pärinevaid metafoore: villhänd, komberjalg (vrd ERIA I: 235 ja 236/7), mille all tuleb mõista lammast ja hobust. Hoopis omapärane on aga Audru tekst, milles nääripoiss edastab oma soovõnnitlusi igale pereliikmele eraldi (ilmselt mardisantide mõju, kus selline pöördumine on reeglipärane): sisse astudes ütleb nääripoiss - n-ö üldise, kogu perele mõeldud - teretuse:

Tere hommikust, tere hommikust!

Pikka iga, rahu, tervist, pisut lapsi, palju leiba!

Edasi soovitakse pereisale:

Rikkaks saada, vanaks elada, põllul vilja kasvada, meres kala püüda!

Siis emale: 
Kümned lehmad lüpsikule, pisukesi lapsi ja palju leiba

( üheksa last ja üks särk)!

Leenile (ilmselt peretütrele):

Viied viinad, kuued kosjad, sajad seitsmendad sõnumed!

Peedule (perepojale?):

Tervist, jõudu töötegijale! (5.132).

Uuemas pärimuses, milles nääripoisid ja -sokud on segunenud, lausuvad nääripoisid juba mitte enam õnnistavalt, vaid nõudvalt:

Meie, uиe aasta poisid, uue aasta ónne toojad!

Kes ei anna sokul juuva selle põld ei kanna vilja (5.48).

Kui soovõnnitlus rajanes veel runolaulu reeglistikule (alliteratsioon, parallelism), siis viimase puhul on aluseks uuema rahvalaulu vorm. Täiesti improvisatsiooniliselt on nääripoiste sõnumiks võetud uuem rahvalaul Oh palu, ristiinime, et lammas sünniks sinine (5.146), mis ei haaku kuidagi nääripoiste tegevusega.

Enne Eesti Vabariigi tekkimist on üles märgitud kaks nääripoiste õnnitlust (5.3 ja 91); 30-ndail aastail viis $(5.36,37,83,112,146)$ ja okupatsiooniaastail 21 (5.25, 26, 31, 33, 39, 40, 48, 49, 86, 88, 96, 97, 98, 100, 102, 120, 123, 132, 139). Sestap peab imestama, et vana vormel on säilinud pikka aega.

Peamiselt Kesk-Saaremaal tuntakse nuutidega nääripoisse. Need ei ole enam lapsed või pisikesed poisid, vaid noorukid või noormehed. Nuutidega löödi pererahvas erguks $(5.34,88,98,102,103,109)$ koos vastava sõnalise vormeliga:

Erguks, erguks; erguks, nooreks!

Vanad valud kadugu! (5.88, ka 98).

Kohati on vormeliga liitunud soovõnnitlus (5.96) või on vormel keeratud naljatlevaks: Erguks, erguks, koerakirbuks! (5.102). Tava viitab taas mardisantidele, kes lõid pererahvast vitsakimbuga terveks. Ent on ka teateid, et nääripoisid on nuutidega vihtunud magajaid $(5.83,108)$ või ähvardanud lüüa andide puudumisel $(5.83,85)$.

Nääripoisse kostitati ja poistest esimene (esimene siseneja) sai kingitusi. Kingituseks olid kindad või sukad-sokid või vööpael (5.14, 18, 49, 53, 54, 60, $70-74,84,86,117,137,138,141,142,145)$ või selleks eraldi valmistatud tubakakott $(5.36,42,45,58,65,69,77,83,93,110)$ sokkidele-kinnastele lisaks. 
On ainult üks teade et nääripoistele kooti varvassokid (vrd sõrmkindad) (5.59). See on taas meenutus mardisanditamisest. On rõhutatud, et kingitusi saab esimene nääripoiss, see, kes varem tuleb $(5.42,54,65,66,71-73,80,81,86$, 89) või kes esimesena kirjutab aastaarvu maja seinale $\sim$ uksele $\sim$ ahjule (5.45). Nääripoiste nuudile kinnitati tutid (5.47, 89).

Arhailisemale ja rituaalsemale annile viitab spetsiaalne kakk (ka nääris) $(5.1,56,91,99,100,108,112,116,119)$, samuti kostitamine õllega (poiste) või viinaga (meeste puhul) - mis pidi tagama nääripoiste soovõnnitluse n.ö. reaalsuse $(5.2,3,15,27,29,35,52,60,63,64,78,79,129,133,137,140)$. Ka raha (müntidena) kuulub n.ö. rituaalse anni juurde. Seda teatakse küll vanemates teadetes, mis kõnelevad tsaariajast $(5.56,80,81,112,124)$.

Pärimuslikuks andeks olid pähklid (nööri otsa aetud nn pähklirõngad). Sageli on rõhutatud, et pähkleid andsid tüdrukud (kindaid-sokke perenaised, kuid tubakakotte peaaegu eranditult tüdrukud) $(5.14,27,28,35,44,49,52$, $60,66,71,72,74,76,79,83,93,105,109,110,113,125,138,141,142,145)$.

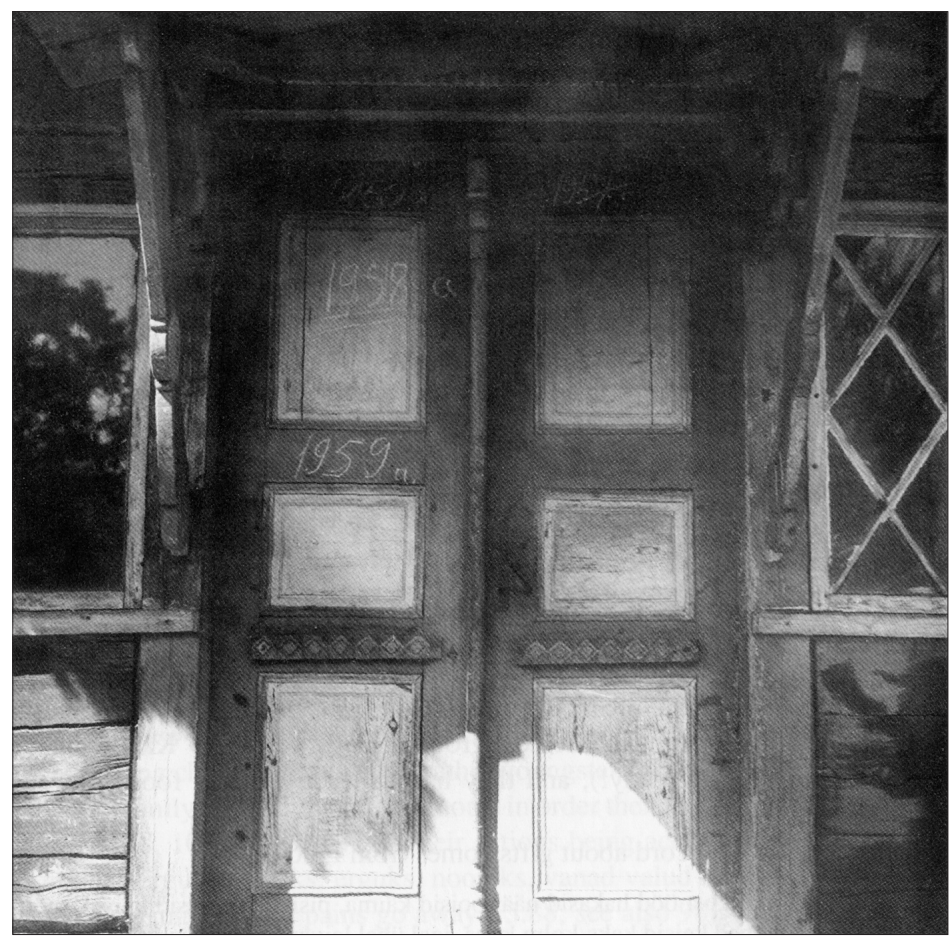

Nääripoiste poolt uksele kirjutatud aastaarvud, Uutalu, Anepesa küla, Kärla kihelkond, 1959. Foto O. Kõiva, Eesti Rahvaluule Arhiivi fotokogu 
Nääripoiste soov olnudki jänu juua ja peotäis pähkleid (5.19). Kui esimene nääripoiss sai andeid, siis teised - kaasaskäijad - pidid leppima pähklitega. Järgnevatele poistesalkadele öeldud: Käisid juba! ja need pidid lahkuma söömata-joomata (5.19, ka 36).

Erandlik teade on Pöidest:

Uie aasta hommikust ööd hakasid nääripoisid käima, pisikesed poisid keisid, möni keis üksi ja möned keisid kaks-kolm koos, igal ühel leivaviilukas käes. Uksest sisse tulles üteldi: tere homikust head uut aastat, head õnne. Ja igaüks pani oma leivaviiluka söömalaua peale. Poistele anti sü̈̈a ja pähkid, olnud üksi ehk kaksi, ja igale mehele anti 2 kopikat raha ka ja leigeti jälle uus viilukas leiba... ja tänati poissa ka önne soovima tulemast. Siis marsiti teise perese, nii pailu kut jöudis, see oli äri, poiste teenistus... (5.124).

Poisikesed käisid leivaviiluga, noormehed aga õllekannuga, mis ühiselt tühjaks joodi ja peremehe poolt uuesti täideti $(5.51,55,135)$. See meenutab õllelaotise viimist ja viimasega seostuvat Jõulu-Tooma pärimust.

Üldiselt vaadeldi tava nääripoisteks käijate poolt. Teiselt poolt on aga huvitav teada, et eelnenud aasta sees abiellunud naised ja leeris käinud tüdrukud pidid nääripoistele midagi kinkima (5.80).

Peale soovõnnitluse esitamist oli nääripoiste peamiseks ülesandeks kirjutada maja uksele, ahjule või seinale uue aasta number (uksele: 5.9, 12, 16, 24-27, $30,45,47,50-52,63,64,82,83,89,120,122$; ahjule: $42,45,52$, 54; seinale: 43 , 45; koht määramata: 22,55$)$. Ja lõbusa vahepalana: kui sisse ei lastud, siis kirjutati uksele vana aastanumber (5.54). Aastanumbrit ei pühitud ära. Seda on näinud kogujadki (5.22). Kuuekümnendaid aastal oli tava veel elujõuline. Tänaseks on taandunud, peamiselt maa-asustuse hõrenemise, noorte linna siirdumise ja laste vähesuse tõttu. 1956. a. kommenteerib üks kohalik kaastööline-rahvaluulekoguja:

Torgu ja Mustjala kandis käis uue aasta poiss. Valjala ja Püha kihelkonnas uue aasta ani, pikka kaila ja nookaga... Pöide kandis aga uue aasta sokk... (5.125).

Näärid on alamsaksa laen (Liin 1964: 43) ja suhteliselt hiline. Tõsi, S. H. Vestringi sõnastikus (umbes 18. sajandi kolmandast veerandist) on: Neari Pääv, Der Neujahrstag (Hupeli 1818. a. ilmunud sõnastikus on küll när vt neär, kuid mitte näärid). Paavst tõi alles 1681. a. uusaasta esimesele jaanuarile. Oletatavasti harjusid eesti talupojad alles 18. saj. esimesel poolel uue pühaga. On tõenäoline, et nääripoiste-tava hargnes vanemast jõulupoiste tavast. Et ennustamine, ennete jälgimine ja uut etappi, s.o uut aastat mõjutavad maagilis-rituaalsed 
tavad keskendusid just uutele jõuludele ehk uuele aastale, siis pole imestada, et nääripoiste tava lõi vohama ja mattis jõulupoiste kombe. Teisalt võib märgata, et nääripoiste tava on kaasanud motiive teistelt külaskäijatelt (sokkudelt, toomalt, martidelt). Ja arvestama peab ka informante, kes nendivad See pole nii vana komme olnd (5.115).

Tänaseks näikse - veel mõne aja eest elujõuline - tava olevat kui mitte hääbunud, siis hääbumas.

Teisedki nääridel ringi liikujad näikse juurduvat vanematest jõulupärimustest.

\section{1.b.4. Jõulu- ja näärisokk (6 ja 7)}

Jõulusokust on aastaist 1889-1979 71 teadet, enamik on kirja pandud 30-ndail aastail. Teated hõlmavad kogu maa, välja arvatud Kirde-Eesti (endine Virumaa). Rohkem on noteeritud teateid aga Lääne-Eestist, kust pärinevad ka hilisemad teated. Tegelast on nimetatud mitmeti: enamasti jõulusokuks, aga ka jõulupukiks ( pukaks) (6.7-11, 13-15, 17, 18, 23, 53, 58-61, 64, 68, 69). Käibel on olnud veel nimetused: sikk $(6.4,30,54,66)$, pokk $(6.16,24)$, oenas $(6.41)$, kits (6.1) ja lokaallaenuna iulbaken (6.12) Reigis. Tähelepanu väärib konstateering Käinast: Nä̈̈risokk oli jõulude ajal ka ja vana-aasta õhtal (6.20).

Jõulusokku kehastasid mehed: poisid (6.55, 64), noored mehed $(6.26,27,29$, $70)$; mehed $(6.59,65)$ ja erandlikult vanem mees (6.66) või vanemad inimesed (6.16). Enamasti on märkimata, kes käisid sokuks, kuid pole ühtegi teadet, et sokk olnuks tüdruk või naine. Vähe on konkreetseid teateid sellestki, kas sokud käisid üksi või hulgi. Nii on teateid, et käisid 30-40 poissi (6.15), et käidi mitmekesi (6.63), mitu sokku kambas (6.40). Rohkem on teateid sokku nööri otsas talutavast poisist või peremehest $(6.14,16,18,34,36)$, ent mainitakse ka lihtsalt sokuga kaasaskäijaid (6.39). Sokkudest mitmuses kõnelevaid teateid $(6.1,3,6,8,22,24,26,27,29,31,40,44,45,55,63)$ on aga vähem kui sokust n.ö ainsuses $(6.2,4$, 5, 7, 9-21, 25, 30, 32-35, 37-39, 43, 47, 51, 54, 57, 58, 61, $62,65,67,70)$. Lisaks on teateid, millest on välja lugeda, kas on tegu sokuga või sokkudega $(6.23,35,41-43,46,53,56,59,60,64,65,68,69,71)$. Ka aeg, millal sokk käis, on teateti üpris erinev: jõululaupäeva õhtu $(6.39,46,47,56$, ka 59 ja 67) ning esimese püha varahommik $(6.5,22,24,26,27,70)$ võib vist tinglikult lugeda samaks ajaks - oleneb ju sellest, millal ringikäimine algas ja millal lõppes. Veel olla sokk käinud esimese püha õhtul (6.18), teisel pühal (6.221 ja 66) ja kolmanda püha õhtul (6.33). Ebamääraseks jääb teade: käis jõuluks ja uuel aastal (6.71). Selles teates on juba tegemist jõulu- ja näärisoku segunemisega. Otsene segiajamine on teates, et jõulusokk käis nääripäeva öösi (6.40). 


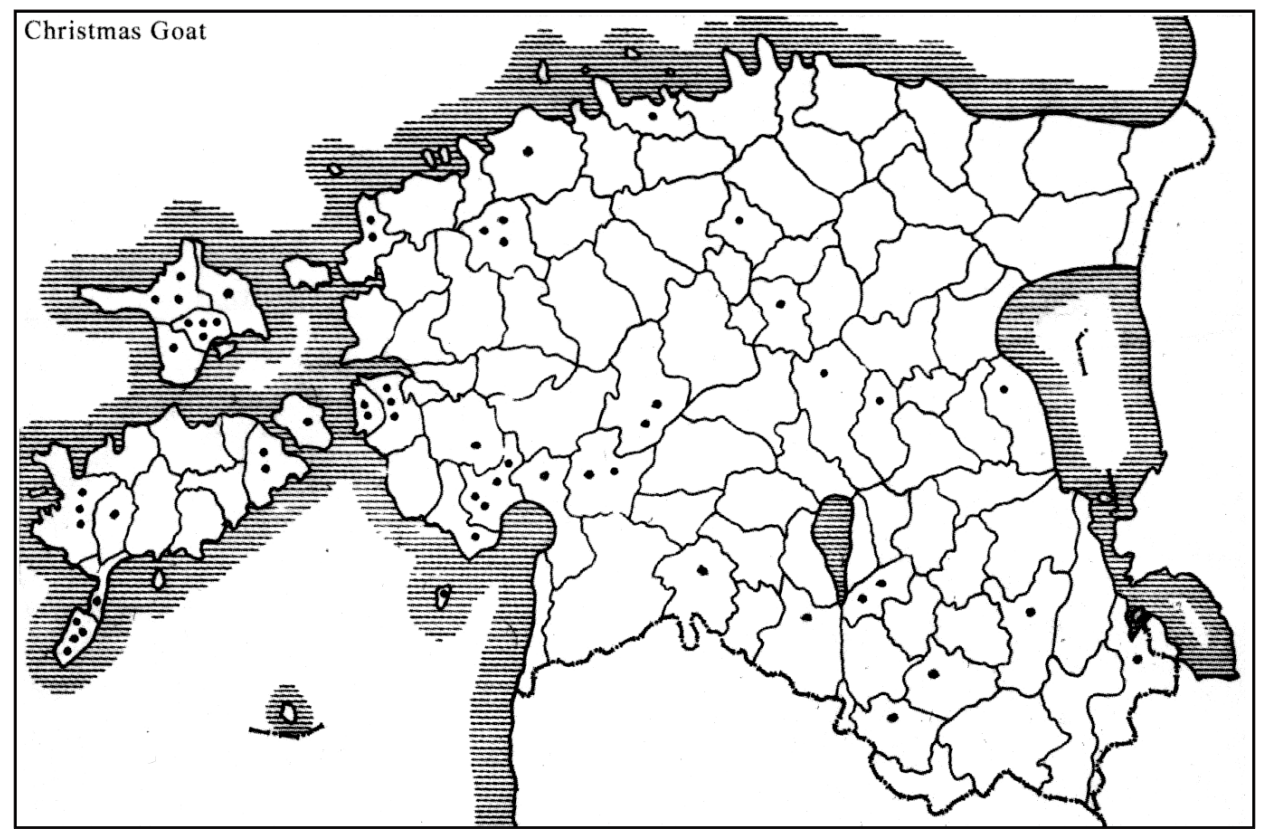

Jõulusokk. Ülo Tedre koostatud kaart.

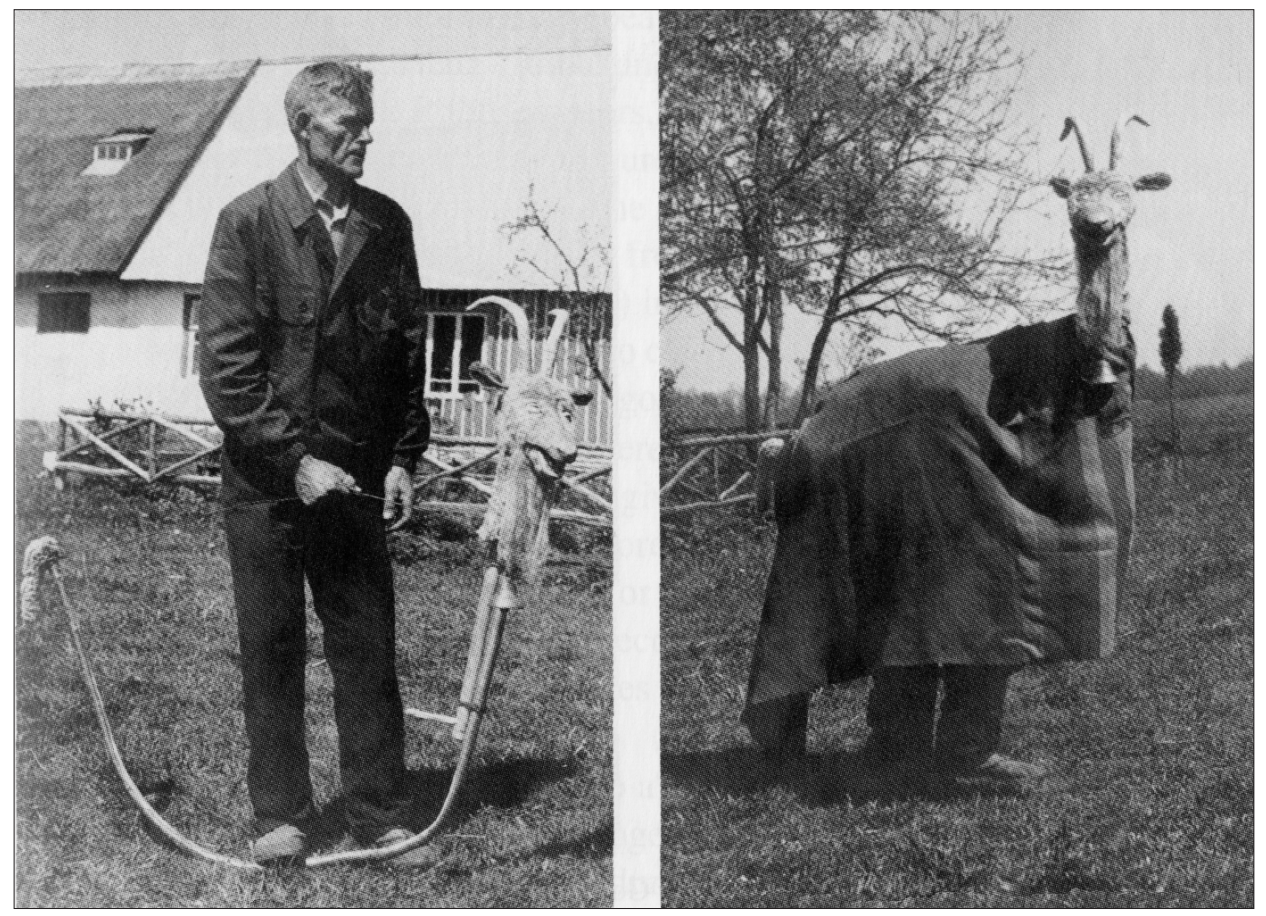

Johannes Liiv demonstreerib jõulusokku, Ahuvara talu, Keskküla, Kirbla kihelkond, 1969. H. Tampere foto, Eesti Rahvaluule Arhiivi fotokogu. 
Soku maskeeringust on olnud juba juttu teises seoses ja seda ei tarvitse korrata üksikasjades ja viitamisi. Põhivahend oli kas jalgade vahele riputatud look (otstesse seotud nööridega üle õla võetud) või käes hoitud teivas, mille esiotsa oli kinnitatud soku pea (pealuu, puust voolitud, õlest põimitud) sarvedega (ehtsad sarved, õlest põimitud, pilbastest tehtud), teise otsa vana viht sabaks. Üle võeti pahupidi kasukas (valge palakas, lina, lihtsalt riie).

Algsest viljakusmaagilisest rituaalkäimisest on veel vaid kaudseid vihjeid: sokud ennustasid majapidamisele head tulevikku $(6.44,45)$, sokk viskas õlgi lakke - rukkiõnneks (6.8). Ka soku tantsimisest, hüppamises, kargamises (6.2, $11,13,34,36,40,45,57,70)$ võib näha naljategemise taga ka rituaalsust. Pärimusteadete järgi tehti sokku meelelahutuseks ja naljategemiseks: sokud tegid soku häält (6.12-14, 16, 22, 34, 36, 40, 45, 70), möllasid ja tegid vigurit $(6.3,8,30,43,51,54)$, poksisid $(6.38,70)$, laulsid $(6.45,47)$, kastsid saba - s.o vana viha - vette ja pritsisid inimesi, eriti tüdrukuid ja lapsi $(6.4,22,33,37$, $43,47,54,70)$. On teateid, kus otsesõnu öeldakse, et sokud tegid nalja (6.19, $51,53,58,59,66,67,69)$.

On tähelepandav, et rida teateid räägivad sokkude tegelemisest lastega: raamat käes, pani lapsi lugema (6.7), viskas lastele ube, pähkleid, õunu, kompvekke $(6.61,63)$, tegi lastele nalja (6.9) aga ühtlasi peksis oma vihast sabaga lapsi $(6.12,22)$, andis saunas olevatele lastele "jõuluhanesid" (s.o vitsakimbuga vastu paljaid kintse) (6.10). Ilmselt on tegemist vana pärimuse ja uudse jõuluvanatraditsiooni segunemisega. Sellele viitab ka otseselt viimane teade. Ent on märgata ka segunemist mardisanditamisega (kaasas kotid, kuhu kogutakse toidukraami või vilja ühissöömiseks või õlle tegemiseks, hiljem tehakse sokupidu) (6.40).

Sokku kostitati eeskätt õllega $(6.6,14-19,25,40)$, saartel anti sokkudele "kaeru", s.o pähkleid $(6.25,39,40,42)$. On märgitud, et sokud said süüa-juua (6.33, 58, 60, 64), leiba (6.62), vorsti ja taari (6.66) või maiustusi (6.67). Ent juttu on ka - rohketest - annetest, täpsustamata, mida just anti $(6.44,45,57)$. Seegi näikse viide mardisanditamisele.

Veel peab märkima, et paljude teadete järgi käisid koos sokk ja hani (6.23, 55, 57, 59-65, 67, 69). Ebamäärasemalt käinud jõulude aegu - mis ilmselt hõlmas ka uusaastat - kits ja karu (6.1); sokk, kurg ja hani (6.2); pukk, kurg ja tont (?) (6.7); sokk pukk, kurg ja tönk (6.50); sokk ja kurg (6.51) ning sokk, karu, kurg ja hani $(6.53,68)$. Täpsemalt on määritletud: käisid jõulusokk ja näärikaru $(6.19,37)$ ning jõulusokk, näärikurg ja kolmekuningakaru $(6.25$, 27). Kolm teadet $(6.31,49,52)$ - Kihelkonnast, Torist ja Hallistest aastail 1937-1939 - kinnitavad, ei tea midagi sokkudest ega teistest loomadest, ainult vanarahva jutt.

Näärisokust on üle maa 306 teadet (ligi kolmandik aga Saaremaalt, mis sõltus niihästi pärimuse populaarsusest kui ka kogumise intensiivsusest: just 


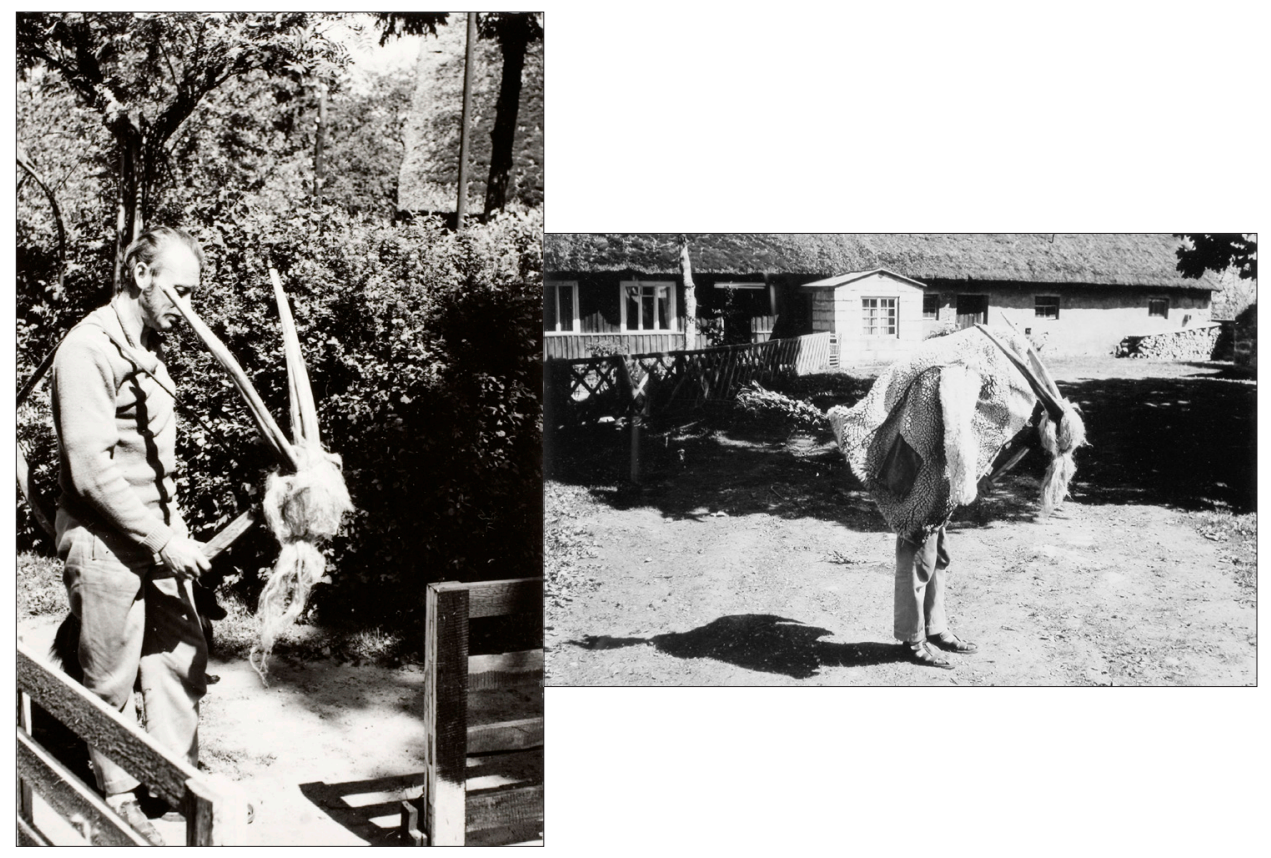

Näärisokk Pöide kihelkonnas, 1975. V. Kutsari foto, Eesti Rahva Muuseumi fotokogu.

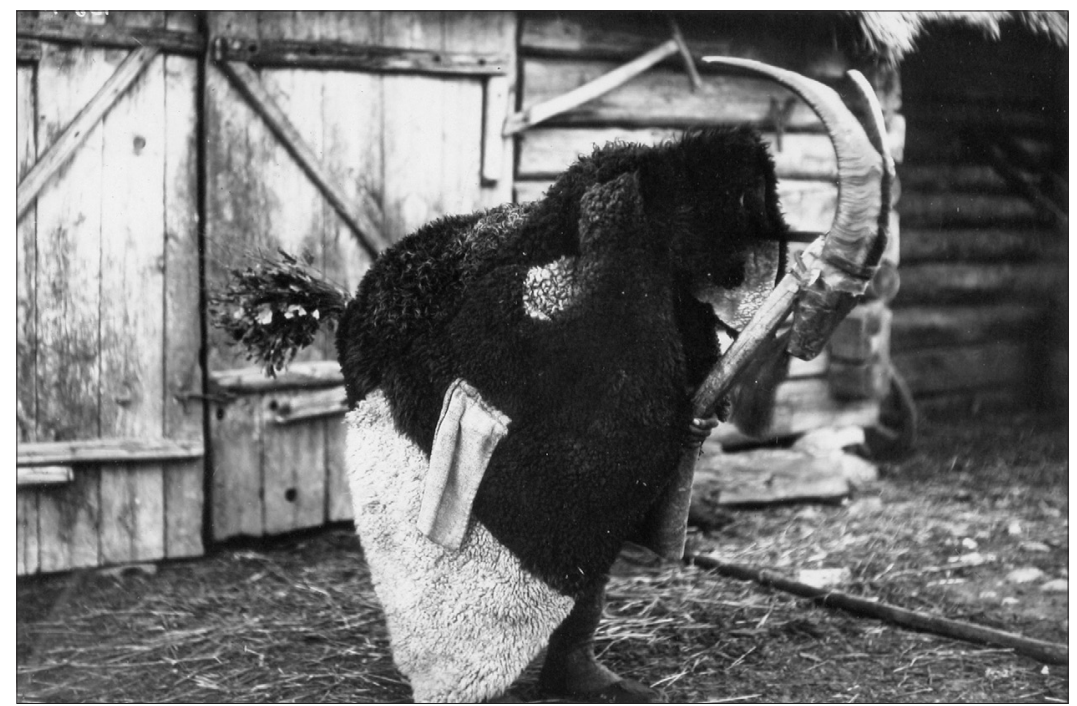

Näärisokk Nõmmel, 1926. Foto K. Grepp, Eesti Rahva Muuseumi fotokogu. 
Saaremaa üldiselt vanapärasemat traditsiooni on innukalt jäädvustatud) ajavahemikus 1872-1989 (tsaariajast 10, tunasest Eesti vabariigi ajast 157 ja nõukogude okupatsiooniaastaist 139 teadet). Peamine nimetus on näärisokk või sokk, veel on kasutusel sikk näärisikk (7.8, 10, 13, 14, 26, 40, 41, 106, 288-292, 294, 300) ning pukk (7.32, 42, 43, 46, 50, 52, 54-60, 63). Kasutusel on olnud ka kits (7.30, 38, 39, 215, 222), kuid mitte alati soku paralleel - või asenimetusena, vaid omaette tegelasena (kes küll välimuselt, käitumiselt jne kattus sokuga). Ainult üks kord esineb nimetus jäär (7.34) - vrd jõulusoku puhul esinenud oinas! On juhtunud, et kasutatud ka nimetust jõulusokk (7.177, ka 172, 259).

Näärisoku valmistajad ja sokuna ringiliikujad olid meessoost: noored poisid, poisid või külapoisid $(7.1,11,15,16,26,30,46,60,64,83,85,88,114,124,129$, $134,136,147,171,181,197,228,233,242,265,266,298)$; noored mehed (7.48, $72,78,81,101-103,111,114,115,135,143,157,175,218,258)$ või mehed (7.4, $22,45,61,93,96-98,116,119,123,252,280,284,291,306)$. Vähesed teated märgivad vanemat meest (7.133, 177, 202, 229). Üks teade nimetab last (7.25). Sageli on kirjeldustes öeldud, et tegijaks oli inimene (7.20, 29, 31, 43, 58, 62, 77, 117, 130, 150, 200, 240, 267, 268, 271, 282, 290, 302) või umbisikuliselt keegi. Ühel korral on sokutaja olnud teenijatüdruk (7.234) - kuid see lõbustanud ainult oma talupere lapsi. Erandlikult on osutatud, et sokuks käisid vaesemad inimesed (7.28). Sokuks käijate ealisust ei saa sobitada geograafilistesse ega ajalistesse piiridesse. Tõsi, vanim kirjapanek a. 1872 räägib mehest ja enamik Saaremaa teadetest kõnelevad poistest või noormeestest. Kõne all olnud laps tegi sokku oma kodutalus.

Järgmine küsimus puudutab aega, millal sokud ringi käisid. Võib julgesti kinnitada, et määrangud: näärilaupäeva õhtul või vana-aasta õhtul, samuti nääriööl ning uue aasta varahommikul - nagu väidab teadete enamik - tähistavad kõik ühte aega, nimelt nääriööd pärast kesköö saabumist (pärast kella 12-st). Erisus johtub ilmselt sellest, millal jutustaja mäletas sokku käinud olevat. Ja see sõltus peale muu ka talu asendist külas. Huvitavam on leida erisusi tavareeglist. Ja need on mitmeti põnevad. Rida teateid ütleb, et näärisokuks käidi jõulude ajal $(7.12,19,39,85,174,231,286)$ või jõuludest kolmekuningapäevani (7.4) või nääridest kolmekuningani (7.92). Märgitakse ka, et käidi nääripäeval $(7.9,20,24,152,237)$ või uuel aastal $(7.38,47,64,123,190)$. Ühe teate järgi käidud annepäeval (7.99). Siit ilmneb seos jõulu- ja näärisoku vahel. Kahe teate järgi (7.25 ja 302) ei olnud sokutegemine seotud pühadega. Esimene teade kirjeldab lapse lõbutsemist, teise autentsus on kaheldav. (Annepäev oli Lääne-Eestis pühadejärgne päev (Hiiemäe 1998: 302). Järgneda võisid veel: Anne lapsepäev, Anne lapse amme päev jne - olenevalt, kui pikaks pühi venitati ja kui kauaks õlut jätkus.)

Kogujad on pearõhu asetanud soku kirjeldamisele, hoopis vähem on konkreetseid andmeid sellest, kuidas sokk või sokud ringi liikusid. Sõnastus on 


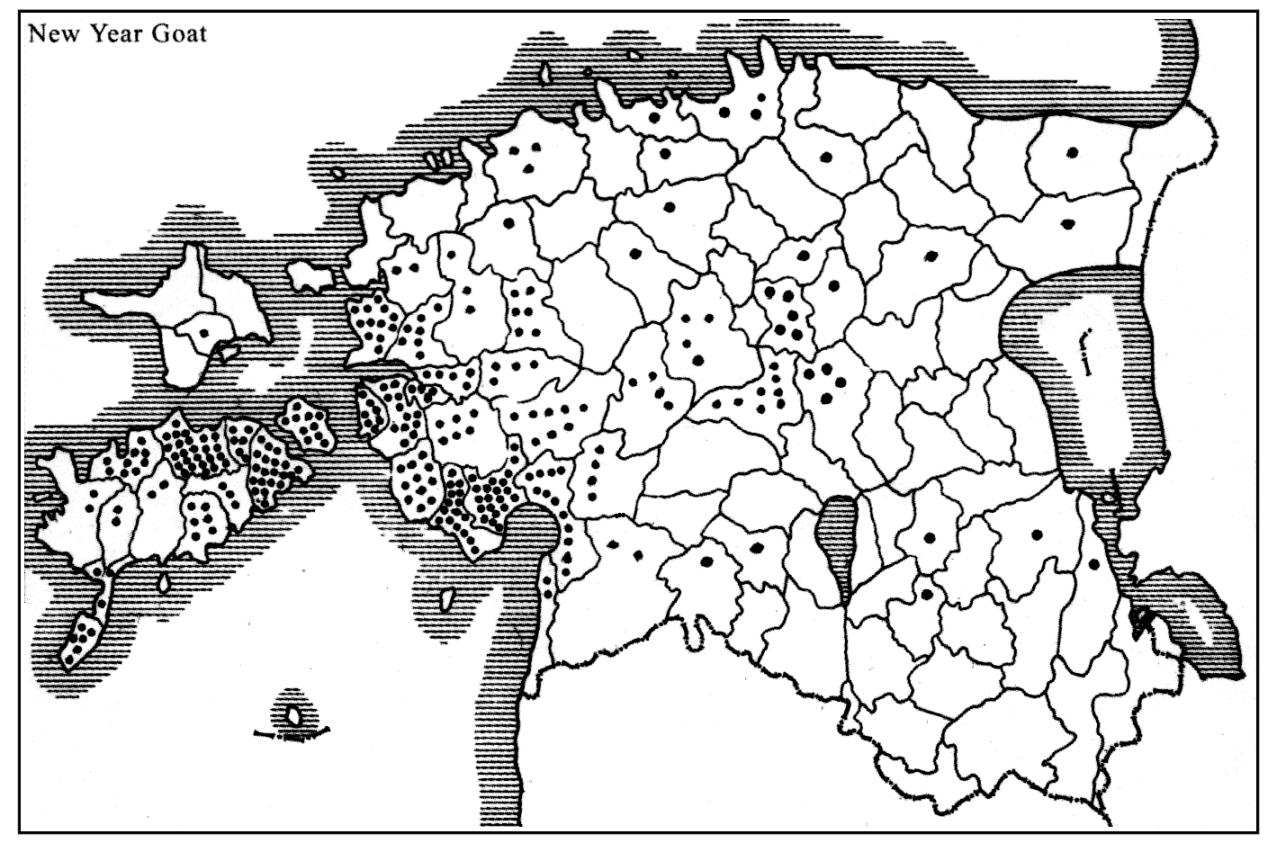

Näärisokud. Ülo Tedre koostatud kaart.

sageli ebamäärane. Näiteks teadet "Nääriööl tehti näärisokku, käisid tarest taresse" on võimalik tõlgendada mitmeti: käis üks sokk või käis üks sokk korraga (järgnesid teised üksiksoku visiidid) või käisid mitu sokku. Sestap on raske kindlalt väita, et käis üks sokk või mitu sokku. Siiski paistab, et Mandri-Eestis käis - enamasti - sokk üksinda, saartel aga käisid sokud mitmekesi või mitmesuguste saatjatega.

Nii käinud koos sokk ja karu (7.107); sokk, karu ja veel keegi (7.11), sokk, karu ja taltsutaja (7.110) ning sokk ja karutantsitaja (7.207) - võib arvata, et küsitletava või küsitleja hajameelsus jättis mainimata karu, sokk ju ei vaja karutantsitajat; samuti sokk ja kurg $(7.218,219,237,258)$. Teateid on ka kolmest maskeeritust: koos on käinud sokk, kits, karu ja kurg (7.39, 103, 198, 209, 244, 247, 260, 262) ja sokk, karu, kurg ning taltsutaja (7.38, 92, 97). Juba sammuke tänapäeva poole on teade, et koos käisid sokk, kits (sama maskeering, aga väiksem ja heledama häälega), karu ja päevapiltnik (7.215) - pildid olid enne valmis joonistatud ja anti pärast "pildistamist" kohe pererahvale kätte. Teade on aastast 1973. Seesuguseid ühekordseid teateid on veelgi: koos käisid sokk, kurg, "ratsutaja" (kahe mehe maskeering: hobune ja ratsanik) ja külapoisid (7.58) või sokk, kurg, hani ja hobune (7.65). Samas on üksikteateid: käisid sokud, karud ja haned (7.132); sokud, karud koos tantsijatega, haned ja kukk (7.140), sokud, kitsed ja karud (7.234); sokud, hani, kurg ja külapoisid (7.202). 
Eriti Saaremaal oli sokul või sokkudel kaasas mitmeti nimetatud saatja või saatjad: sokk ja karjased (7.274) või sokupoiss $(7.28,158)$ või vedajad (7.126) või talutaja (7.240) või pulmalised $(7.271)$ või sokuhoidja ja poisid $(7.129,157)$ või nuudimees $(7.300)$ või kaks talutajat $(7.277,298)$ või taltsutaja $(7.46,60$, 177) või ebamäärasemalt: poisid $(7.124,156,199)$ neli-viis poissi $(7.136,206)$, mehed (7.128, 204, 230, 249), kamp noormehi (7.48, 51), saatjad (7.30, 68, 72, 74, 83). Tuleb märkida eraldi, et saatjateks olid ka nääripoisid (7.20, 52, 142, $163,185)$ ning mõnikord on samastatud nääripoisid sokkudega $(7.202,215)$.

Ka mitme - kahe-kolme - soku puhul on saatjaks olnud karjane (7.13, 22, $66,120,134,141,144,145)$, poisid (7.85) või nääripoiss (7.187) või peremees (7.297) või ajaja (7.193). Ebamääraselt on vihjatud saatjatele: teine kõrval (7.275), seltsilised (7.214), oma selts (7.44), kamraadid kaasas (7.19, 49, 51), muidu mehed (7.179), väikesed poisid (7.147), järgikäijad koos pillimehega (7.154) või lihtsalt teised (7.250).

Sokku käsitati õnnetoojana (7.12, 137, 176, 178, 194, 199, 230). Ootustele vastavalt sokk või tema saatja soovisidki talule või perele õnne ja edenemist $(7.2,23,37,40,48,59,74,114,129,139,160,171,182,185,190,196,217,245$, 249, 277, 298). Looma-, vilja-, peiu- ja pruudiõnne soovimine on hiljem taandunud uue aasta soovimiseks (7.23, 42, 43, 101, 114, 127, 143, 149, 152, 175, 182, 224, 275). On teateid: kui sokud ei käinud, siis oldi pahased, et peavad halvaks $(7.85,89)$.

Esialgse funktsiooni - õnne toomine - tuhmumisel hakkas domineerima maskeeringust lähtuv esinemine. Sokud mökitasid või tegid soku häält akna taga, tuppa tulles ja toas $(7.4,8,24,100,122)$. Toas puksisid pererahvast, eriti tüdrukuid $(7.4,6,15,40,44,69,89,127,133,134,137,142,143,148$, $150,151,160,169,183,185,206,222,291$, 306) või omavahel - kui käimas oli sokukari (7.31, 131, 137, 152, 153). Kõige levinum temp oli saba (s.o vana viha) kastmine veepange ja saha raputamisega pritsida majalisi, taas eelistavalt tüdrukuid (7.8, 15, 30, 32, 46, 51, 74, 80, 86, 88, 90, 91, 93, 110, 119, 124, 140, $143,146,156,177,198,217,219-221,230,232$, 234, 241, 243, 245, 247-249, $252,253,264-266,279,291,294,296,306)$. Ent on ka üksikteade, mille järgi sabaga veepritsimine "oli talu õnnistamine" (7.279). On esmapilgul kummalisi teateid, et vett pritsitud pange kastetud õlgedest sarvedega $(7.267,268)$. Need on õpilaste kirjapanekud (Pärnu-Jaagupist a. 1930) - võimalik, et küsitlejad olid pealiskaudsed: soku kirjeldustes ei mainita saba, seega tuli veepritsijaks oletada sarved, mis on väga ebatõenäoline (õlg imab vee sisse ega võimalda seda oluliselt pritsida, kõnelemata koomilise efekti puudumisest). Teisalt on teateid, et sabaga vihuti vett siis, kui pererahvas ei kostitanud või ei andnud ande $(7.52,219,233,298)$. Sama on väidetud puksimise kohta: "Nad poksisid pererahvast ja ennem ei jätnud järele, kui neile nõutud asi anti. Enamasti 
anti näärisokkudele õlut” (7.271). Samuti valitses arvamus: kui sokku sokke ei kostitata, siis viib viivad talu õnne ära $(7.22,137)$. On väheseid teateid ka agressiivsemast käitumisest: Sokk... jooksis ümber kõik, sa ju tead kui elajas tuas on (7.124, ka 242) või ajas teisi taga, pusis, kaevas (7.15, ka 19). Eriti on märgitud tegelemine lastega: ajab lapsi taga (7.119, 306), hirmutab lapsi (7.234, $253,257,278,284,293,306)$, ajab tüdrukuid taga $(7.45,58)$, kollitab arglikke (7.100). Kohati on näärisokk omandanud mardi-kadrisandi funktsioone, lauldes ukse taga laske sokud sisse $(7.149,252)$ ja kontrollides laste lugemis- ja tüdrukute heegeldamisoskust (7.223).

Hoopis mõistetavam on näärisoku ja nääripoiste funktsioonide samastumine. Nii pidid sokud kirjutama kriidi või tahmaga uksele (korstnale) aastaarvu, millal nad peres käisid (7.45, 61, 135, 152, 154, 192, 215, 225) ja ütlema vastava sigivussalmi:

Tüdrukud mehele, poisid kosja, sead sigima, kanad munema (7.187)

või

\author{
Sigigu sikuksed, \\ kasugu karujaluksed, \\ kanad munele, \\ üks õuest mingu, \\ üheksa õue tulgu (7.188, ka 49, 158, 171).
}

Ühe teate järgi - tõsi, see on esitatud isa-ema mälestusena - samastatakse näärisokk jõuluvanaga: annab lastele kingitusi ja kuulab nende salmikeste lugemist (7.285). Üksikteade ütleb näärisokkude ülesandeks viljasaagi ennustamiseks lakke loobitud ja parte külge jäänud õlekõrte maha niitmise (7.201). Samuti üksikteate järgi etendasid näärisokk ja talutaja kingsepa mängu - sokk silma pistjana ja talutaja löögi kõrvale juhtijana (7.240). Seesugused konkretiseeritud tegevused on kirjeldustes siiski haruldased. Enamasti öeldakse üldsõnaliselt: sokk tembutab, teeb nalja $(7.2,33,69,83,115,203,218,222,244,258,280,297)$ või hüppab, kargab, tantsib (7.2, 16, 70, 163, 209) või tantsib ja laulab (7.225). Kui hakkas tuhmuma esialgne rituaalne-õnnetoov sanditamine, siis muutus üha domineerivamaks sokuks käimise mängulisus. Mõnigi kord on seda lausa rõhutatud. Olgu näiteks Karuse tekst a-st 1968:

Kui poisid sisse tulid, siis küsisid: "Kas võeramaa loomi ka näha tahate?" Sokud olid, mitu tükki, ukse taga. Kui peremees lubas, tulid sisse, puksisid ja tegid oma nal'la. Pill oli ka ühes. Peaaegu korrast käisid kõik talud läbi. Igas kohas, kus suits tõusis. Kui vahele jäeti, siis üteldi, et nii kui põimivad või peavad alvas. See läks öö läbi, omikuvalgeni (7.85) 
või Mustjalast a. 1976:

Õhta sai... me olime vanaeidega põhkus... äkki üks pisike vanamees tuleb uksest sisse, all kampsun üll, käed sedasi rinna ees, teritab. Vanamees võttis - istus laua taga, luges piiblit - võttis tere vastu ja. Näd oo söapögeneead - siis oli juba söda väljas - näd oo söapögeneead, et jälle ehk saaks öömaea. Vanamees ütleb sedasi: Jah, noh, kus te siis lähetegid öösse änam, et öömaea ka saab. - Ä ma pole üksi, mool on loomi ka. Vanaeit ütleb: Püha Jeesus, kus me’s need loomad nüid täna öese paneme! Vana ütles sedasi, et tee uks lahti, lase nad tuba tulla! .... Tegi ukse lahti ja olid sokud sihel ka, igavene kari oli neid, üks neli-viis tükki... kukkusid puksima, kukkusid jummima seel sihel. Äkist kellu löi kaksteisend - oh sa püha Jeesus, loogad jäid sinnasamasele seina ääre jälle ja pistasid ise uksest välja. Mitte ühel es ole änam aega vaata. Vaada, kellu oli kaksteisend, siis tahtasid nä̈̈ripoisteks ju minna.... (7.167).

Üldiselt kostitati sokkusid ja nendega kaasaskäijaid. On mainitud üldsõnaliselt: anti süüa-juua (7.175, 197, 297, ka 22, 57, 140, 202 ja 185). Huvitavamad on teated, mille järgi sokud nõuavad või saavad ube-herneid (7.27, 28, 133, 137, $153,182,187)$. Nimelt on oad-herned vana rituaalroog teispoolsusega kontaktis olnud isikutele (näit. surnuvalvajad). Kas õnnetoovad sokudki olid teispoolsuse esindajad või vahendajad? Lääne-Eestis olid sokkudele antavaks üldiselt pähklid (7.9, 68, 88, 129, 132, 133, 135, 153, 174, 182, 190, 195, 205, 206, 211 , 250), mida nõuti või pakuti ka kaerana (7.82) või "koorega kaerana" (7.68). Pähklite kõrval anti õunu (7.45, 49, 59, 137, 161, 187, 202, 209) ja maiustusi (7.38, 139, 205). Toiduaineid - saia, leiba, näärikakku, vorsti või makki - mainitakse harva $(7.9,19,99,115,137,185,187,285)$. Ometi on üksikteateid, et sokul või sokupoistel olnud kott kaelas $(7.98,187,188)$ korjamaks andeid või kaeru (s.o pähkleid) (7.10) või vilja linnase tegemiseks (7.125). Vilja saamiseks olnud sokul kaasas vastav tunniskiri.

Toidust olulisem oli kostitamine õllega, mis on tuntud üle maa $(7.11,16,45$, $48,49,52,57-59,98,99,110,115,129,132$, 133, 135, 153, 161, 166, 175, 202 , 205, 271, 282, 298). Hilisemad teated lisavad õllele viina (7.22, 38, 71, 216, 249 , 291). Ainult vähesed teated mainivad ainult viina $(7.250,255,298)$ ning üksikteade veini (7.48). On ka üldsõnaline pakuti juua (7.185) ja eristav: peremees pakkus juua, perenaine süüa (7.28). Hilisemad teated märgivad - mõnevõrra õelalt, ent usutavasti õiglaselt - et õlle pärast käivadki mehed sokku tegemas (7.135, 158, 211, 216, 245, 280) või käivad sokuna õlut norimas $(7.162,214,233)$.

Pärimuste segunemisele viitab teade, et sokul olnud kaasas lähker õllega (7.188) või õllekapp (7.296). Pikem seletus küll puudub, kuid võib mõista, kapp lähker joodi külastatavas peres ühiselt ja täideti enne sokkude lahkumist 
taas peremehe poolt (vrd toomastega). Tembutuse hulka kuulub kaasaskantav viinapudel, millest juua pakuti - paraku oli pudelis puhas vesi. Peamiselt Saaremaal on tavaks teha sokkudele muidki annetusi: kindad (7.129). kindad ja sokid sukad (7.1, 7, 27, 108, 168, 174, 190, 195), kindad ja sukapaelad (7.136, 144), kindad, sukad ja paelad (7.28). Need on tavaliselt seotud soku sarvisse. On ka teade, et kindaid-sokke sai ainult taluperet esimesena külastanud sokk, hilisemad said ainult õlut) (7.168). Erandlik, ent ilmselt vanade juurtega on teade, mille järgi sel aastal leeris käinud peretütar pidi sokule andma kindaid ja sel aastal tallu naitunud noorik sukapaelad ja kindad (7.177). Pärimuslikuks kingituseks on olnud ka neidude väljaõmmeldud tubakakotid (7.190). Märgitakse sedagi, et sokk ei lõpetanud tembutamist ega lahkunud enne kui oli andeid saanud (7.183, 188, 219, 233, 271, 301, 306). Siia kuulub ka erandlik teade, et sokk pritsis sabaga vett pererahvale siis või seni kui midagi ei antud (7.298). Erandlik näikse olevat seegi teade, et kingitusi said sokupoisid, mitte sokk (7.142). Vähesed teated - sõjajärgsetest aastatest - ütlevad, et sokule ei antud midagi (s.o andeid) (7.146, 148, 275).

Sokuks käimisel on arvestatud soolisi-ealisi piiranguid. Ainult ühes teates osutatakse sotsiaalsele piirangule:

Sokuks käisid vaesemad inimesed, vabadikud ja popsid. Teised seda ei harrastanud. Olen ise sokuks käinud küll ja küll. Mäletan, et ükskord sain ühe öoga kümme paari sukke ja kindaid ja samapalju paelu. Hommikuks oli terve küla läbi käidud (7.28).

Teade pärineb Keilasse asunud Karja kihelkonna asukalt s. 1942.

On üksikteateid, et küsitletavad pole ise näärisokku näinud, aga sellest on kõnelnud vanemad $(7.5,283,285)$, seda on tehtud vanasti $(7.79,164,172,281)$, on tehtud naaberkülas (7.18), on täpsustatud: käidi Eesti ajal (7.53), enne sõda (7.210), käisid 1939. aastani ja nüüd (1970-1972) jälle (7.251), viimati käidi umbes a. 1950 (7.211), on käidud viimase ajani (7.251), viimati käidi umbes a. 1950 (7.211), on käidud viimase ajani (a. 1956) välja arvatud sõja-aastad (7.209). Huvitav on teade lisakust (a. 1955): vanasti ei käidud näärisokuks (7.3). Folklorismile viitab teade Märjamaalt (a. 1950): oppilased on hakanud näärisokku tegema (7.35). Päris eitavaid teateid on ainult mõni: Kuusalust (7.17), Märjamaalt (7.34 ja 36), Mustjalast (7.165), Jämajast (7.180), Vändrast (7.276). Need on juhuteated, kuna vastavatest kihelkondadest - eriti Saaremaalt - on ka positiivseid teateid. Esiletõstmist pälvib ühe koguja arvamus 1903. aastast: See mood on 50 aasta eest suurem olnud, mis vist lätlastelt Saaremaale toodavaks võiks arvata, kes kaua aastaid Saaremaal metsatöös olid (7.113). Arvamuse tõesus on kaheldav. Küll aga võib toetada väidet, et saarlased on - kraavikaevajatena ja müüritöölistena - kommet tutvustanud ja levitanud Mandri-Eestis (7.27). 


\section{1.b.5. Kolmekuningapäeva sokk (8)}

Kolmekuningapäeva sokust on seitse teadet aastatest 1927-1956 tinglikult üle maa. Nende maskeering ja esinemine ei erinenud eelnevatest. Ainult kostitamisest on vähe teateid (tegelikult ainult kord mainitakse sokule antavat: sepik, pähklid, munad jne (8.1)).

Kokkuvõtvalt julgen väita, et algne on jõulusokk. Alles nääride n.ö eraldumisega jõuludest muutus domineerivaks näärisokk. Sokk viljakusesümbolina sobis siirderituaali, mis iseloomustab aastavahetuse tavasid.

\section{1.b.6. Jõuluhani (9 ja 11)}

Jõuluhanena tuntakse vitsalööki saunas paljale ihule. Iseloomulik on teade:

Jõuluhani on tuntud minu teada Põhja-Eestis, kus ta veel praegugi /a. 1930/ vana kombena tarvitusel. Jõuluhane antakse saunas, kus inimesed parajasti jõulu eel vihtlevad või pesevad. See on nagu mingisugune heatahtlik vingerpussi mängimine teistele. Muidugi keegi ei taha jõuluhane saada, vaid püüab selle eest, kui vähegi võimalik, kõrvale hoida. Jõuluhane andmine on harilikult kadaka-, kuuse-või kaseraoga või -vitsaga löömine vastu paljaid kintse või paljast tagumikku. Sealjuures räägitakse, et hani hammustas (11.2).

Analoogilisi teateid on aastaist 1890-1957 33, eelistavalt Lääne-Eestist. Sellele tavale vihjab juba Russwurm (1855) rannarootslaste juures, nimetades vitsu julgâs, julgans, niisiis jõuluhaneks. Reeglina on see peresisene mäng ja hane andjaks on tavaliselt pereisa. Ainult kahe teate järgi on haned vöörad: ühe järgi (11.28) ootasid ja said ande, mis viitab segunemisele maskeeritud hanega; teise järgi (11.30) luurasid haned - antud juhul poisid - sauna juures siis, kui tüdrukud olid pesemas. Enamasti teevad vitsa andvad haned hane häält või ütlevad: "Näkk, näkk, näkk!", ent kohtame ka sõnumisi, näiteks: Mida valusam, seda teravam tervus uuel aastal! (11.4). Enamasti on kombe sisu teadmata, ent kohati seostatakse seda õnne ja rahu toomise $(11.6,21)$ või jõu ja tervise andmisega $(11.31,32)$. Teisal on tast saanud lastehirmutis, kellega ähvardati sõnakuulmatuid või halvasti õppivaid lapsi $(11.11,14,15,16,20$, 23, 24). "Hane andmist" esines jõuluõhtu kõrval ka nääriõhtul $(11.2,4,5,18)$ ja koguni lihavõtte ajal (11.2).

Usutavasti sellest kodusest tavast kasvaski haneks maskeerimine ja sellisena külapidi käimine. Esimene trükiteade näikse pärinevat 1872. aastast (Holzmayer 1872: 56). Teateid jõuluhanest on aastaist 1887-1986 78 üle maa, 
rohkem aga Lääne-Eestist, kus tava on ilmselt kauem püsinud. Haneks maskeerimised ennast tüdrukud või naised (9.5, 32, 51, 59, 60, 64, 67-69, 71, 72, $74,75,78)$ - seda eelistatavalt Ida-Eestis. Lääne-Eestis, eriti Saaremaal on pilt kirevam. Seal on haneks käinud mehed $(9.14,16,28,34,51)$, noored poisid $(9.35,48,54,79)$ või lihtsalt noored $(9.50)$, aga ka lapsed $(9.24,52,53)$ - viimased juba tava hääbumisperioodil.

Ka käimisaeg on varieeruv: käidi 3 päeva enne jõule (9.79), jõululaupäeval kell kaksteist (9.14, 39, 48, 51), jõululaupäeva õhtul (9.27, 29, 30, 35, 43, 46), jõuluhommikul (9.26), esimese püha õhtul (9.53), kolmandal pühal (9.47), vanaaasta õhtul (9.50) ja uuel aastal (9.61). Enamik teateid viitab jõululaupäevale, mis ongi kõige tõenäolisem käimise aeg. Et jõuluhaneks käiakse ka vana-aasta õhtul ja uuel aastal, osutab jõuluhane ja näärihane vähesele eristumisele. Haneks käidi üksi (9.51) või hulgakesi (9.53). Need üksikteated ei anna pilti tegelikust käimisest. Mõnevõrra rohkem on andmeid mitme maskeeritu üheskoos käimisest: sokk, jõulusokk ja jõuluhani $(9.57,58,70)$ aga ka näärisokk ja jõuluhani vana-aasta õhtul (9.50); sokk, karu ja hani (9.2); pukk, sokk ja hani (9.76); sokk, hani, kurg ja hobune (9.6) ja pukid, sokud, karud, haned, kured (9.77).

Maskeering on lihtne, võiks öelda, et kokkuleppeline: ümber on võetud pahempidi kasukas, varrukast on pistetud läbi kõver kepp või kook - see on hane kaelaks ja nokaks - vana viht on sabaks, üks käsi hoiab nokka, teises käes on vitsakimp - hanede andmiseks $(9.5,56,62,75,78)$. Ümber on võetud ka valge kasukas (9.9) või valge lina (9.32) - meenutamaks rohkem hane.

Nagu sokust nii ka hanest loodeti õnne ja head tulevikku $(9.57,58)$. Konkreetsemalt usuti, et hane nokkimine toob õnne nii inimestele kui loomadele ja peletab pahu vaime (9.13).

Haned tegelesid eeskätt lastega: nad loetasid lapsi (9.1, 8, 9, 26, 43, 53), enamasti aga ähvardasid ja hirmutasid (9.7, 25-27, 31, 32, 40, 51, 55, 61, 73, 77). Üksikteate järgi äratas hani magajaid (9.26), nokkis toasolijaid (9.23, 28, $30,60)$ või ähvardas vitsakimbuga lüüa $(9.56,62,69,72,75)$. Viimane seostub ilmselt "hane andmisega" saunas, kuid seda võib käsitada ka nokkimise teisendina, mis pidi teatavasti õnne tooma. Mõned teated on sellestki, et hani kastnud saba vette ja pritsinud toasolijaid $(9.1,12,38,41)$, mis on ilmsesti ülekanne sokutamisest. Seevastu on teateid sellest, et hanele visatud vett kaela hüüdega "Ega hani vett karda!" või "Ega hani või veeta elada!" (9.60, 63, 65, 66, 69, 70, $72,78)$. Ka hani tahtis ja sai õlut $(9.9,11,14,29,37,43,54)$. Vitstest, so. hane andmisest loobumise eest nõudsid haned "lunastust" ehk andeid (9.5, 56, 69, 75, 78). Ka nokahoobist võisid anded päästa $(9.15,23)$. Saaremaal (Karja ja Pöide kihelkonnas) käisid haned nimelt saunas pesijaid kimbutamas (vitsutamas või nokkimas) $(9.29,30,32,33,51,54,55,77)$. Nende jaoks oli sauna 
õlut toodud. Hane kostitati lisaks õllele ka pähklitega $(9.43,53)$, jõulutoiduga (9.16), suupistetega (9.71). On antud ka andeid - lähemalt määritlemata, mida just $(9.2,57,58,63,66)$. Erandlik on teade, et hane etteasteks olnud hanekisa tegemine akna taga (9.46).

Tava on käibelt kadunud ja ainult mälus säilinud. Kuressaare linnast teatakse 1935. a.: isa ei mäleta (9.44); Karja kihelkonnast 1959. a. teatatakse: Nüüd pöle aned enam käinud (9.31-33); Pöidest 1961. a.: pole paarkümmend aastat olnud; ja Mustjalast 1975. a.: hanesid pole enam olnud, aga neist on räägitud.

\section{1.b.7. Näärihani $(9)$}

Näärihanedest on aastaist 1892-1978 ainult 14 teadet (Lääne-Eestist, enamasti saartelt). Neid nimetatakse näärihaneks (9.85, 88, 89, 91-93), uueaastahaneks (9.83), lihtsalt haneks $(9.81,82,86,90)$, aga ka jõuluhaneks $(9.87,94)$. Näitaks viimane teade: "Mõned kohas käis jõuluhani ka uuel aastal lapsi vitsaga hirmutamas." Näärihaned on käinud peresid mööda näärilaupäeva õhtul $(9.84,85$, 87), uue aasta hommikul (9.81), nääripäeval (9.92, 93), uue aasta õhtul (9.86) või täiesti ebamääraselt uue aasta alguses (9.86) ja uuel aastal (9.83, 92, 94). Haneks maskeeritu soost on ainult üks teade: see olnud meesterahvas (9.91). Teine teade ütleb: tegijad olnud noored (9.85). Kahe teate järgi võib oletada, et hanesid oli mitu $(9.85,87)$. Näärihane maskeering on sama, mis jõuluhanelgi. Ka tegevus näikse olevat jõuluhanega identne (sellest on ülepea vähe juttu). Juurde on tulnud uue aasta õnnesoovid (9.91). Ka kostitus on sama. Võib küll järeldada, et näärihani on jõuluhanest lähtunud. Ainus teade on hanest kolmekuningapäeval (9.95): Kolmekuningal tegid kolmekuninga hane ja käisid peresid mööda.

Erandina tahan märkida üht Karuse teadet a-st 1938, kus jõuluhaneks käimist seostatakse sotsiaalse kihistumisega: Jõuluhaned - niisugused vaesed inimesed perest peresse armust saama, kerjamas. Enne jõule keisid. Öeldi: “Jõuluaned tulevad.” Üldiselt usaldatava korrespondendi (V. Eenveer, s. 1913) teates pole põhjust kahelda. Küsimus on informandis: kas ei mõistetud küsimust või taheti - kommet tundmata - midagi vastata. Igatahes on see väga erandlik teade, millele ei näi leiduvat paralleeli. Teisalt pole ju võimatu, et jõuluhaned - martide-kadride eeskujul - tõesti andeid korjasid.

Küsimus on, miks hani? Hane erilisest pühakspeetavusest ei näi olevat andmeid. Tuleb siiski märkida, et hani esineb sageli meie lüro-eepiliste laulude vanemad kihistuses (vt ERIA I 1969: 77/8 samuti on osundusi hane seotusest teispoolsusega (Loorits I 1949: 349 ja 350, II 1951-53: 137 ja 247, III 1957-1960: 197). See ehk seletabki hane valimist jõulusanditajate üheks maskeerimisobjektiks. 


\section{1.b.8. Karu (12)}

Karu kohtame sanditajate seas nii jõuludel, uuel aastal kui ka kolmekuningapäeval. Jõulukarust on 21 teadet aastaist 1929-1964 hõredalt üle Eesti (Saaremaalt ainult üks teade); näärikarust 27 teadet aastaist 1927-1975 eelistatavalt Lääne-Eestist, kolmekuningakarust 5 teadet aastaist 1938-1968 Läänemaa kahest kihelkonnast (Hanila ja Karuse). Karuks käis või käisid (noored) mees mehed (12.3, 9, 14, 20, 22, 23, 36, 40, 44, 45, 49). Ainult ühe teate järgi võib kaude aimata, et karuks maskeerus vanatüdruk (12.53). On ka märgitud, et käisid noored (12.19.27); mõistagi on kirjeldustes öeldud, et karuks oli inimene $(12.17,32)$ või isik (9.48) või umbisikuliselt keegi $(12.4,5,8$, 15). Karu teotsemise kirjeldustest tuleb aga järeldada, et tegemist oli meessoo esindajatega. Ainult ühe teate järgi võib väita, et karu käis üksi (12.51). Teisalt näikse kolmekuningapäeval ainult karu mööda peresid käinud, vähemalt Hanilas ja Karusel (12.49-53). Kuigi karu oli üks, käis ta tavaliselt küllalt kirjus seltskonnas. Kindlasti oli kaasas taltsutaja tantsitaja (12.5, (6), 14, 20, $22,25,29,32,36-38,40,48)$ või tantsitajad (12.9, 13, 15, 17, 31, 34), aga ka teisi mehi (12.13), pillimees ja kotimees (12.39). Tavaline saatja karule oli sokk (pukk, kits) - vastavalt siis jõulu- või näärisokk (12.8, 19, 23, 28-30, 37, 41, 52) oma poistega (12.37) või nääripoisiga (12.40). Sagedaseks kaaslaseks (nääri-) karule oli ka kurg koos (kitse, puki) sokuga (12.25, 26, 31, 39, 42, 46, 47) ning hani, ikka koos sokuga (12.33) või ainult kurg (12.45). Ent on ka teateid, et koos käisid peresid kaudu peaaegu kõik, keda maskidena kujutati: sokk, karu, kurg, hani (12.8.21); sokk, karu, hani, kukk (12.34), karu ja teised loomad ja linnud (12.35). Ühe teate järgi käinud karud ja hundid inimesi hirmutamas (12.17). See on ilmne tahtlik või tahtmatu eksitus - hundimaskist pole juttu üheski seoses. Kui juba hundi nimetamisest kardeti looma kutsumist, mida siis veel maskist oodata.

Ühe teate järgi (12.31) käisid kaks karu, ebamäärasemad on vihjed, mis räägivad karudest (s.o mitmest karust) $(12.19$, 34, 44). Huvitavad on aga pärimusteated, kus samastatakse sokk ja karu (12.16): kus näärisokuga käib kaasas karutantsitaja $(12.6,38)$ või kus karule tehakse maskeerimisel sarved pähe ja saba taha (12.2). Seesugusel pärimuste segunemisel pole kindlat piirkondlikku tausta, küll võib aga öelda, et soku-pärimus näikse prevaleerivat (tarvitsemata olla vanem). Mõned teated ütlevad, et karu tehti kodus laste hirmutamisekslõbustamiseks ega käidud sellena külas $(12.2,7,50)$.

Maskeeringuks kasutati pahupidi kasukat:

Karul on pahupidi kasukas seljas. Jalad pannakse kasuka käistesse ja teine kasuk pannakse ülemise kehaosa ümber. Kätte pannakse pahempidi kindad ja pähe müts (12.13, ka 32) või Mees kahe kasuka sees. Näokatet 
ka. Laud pandi selja peale. Tantsitaja võis siis nuiaga laua peale lüüa kui karu läks vihaseks (12.14, ka 40).

Üks osalenu tunnistab: Karu elu oli raske, ei taht keegi. Kaks kasukas oli selgas ja tuad palavad, siis läks nahk märjase ja mine väl'la - saad külma (12.30). Küllap seepärast piirdutigi ka ühe kasukaga $(12.2$, 4, 5, 8, 9, 12, 15, 20, 25, 27 , 43, 45, 48). Laua asemel on kasutatud ka patja:

Karule on pandud hästi pehme padi, mis on ka paks, selja peale, mille pihta siis tantsitaja suure poomiga peksab... (12.36)

või

...Karul oli padjalasu selgas, see oli kasuka all. Sellepärast ta / s.o tantsitaja/ ka senna lü̈̈a võis... (12.50).

Tavaliselt oli karule seotud ümber kere ohelik (nöör, pael, kett) - teine ots tantsitaja käes.

Karu käis samal ajal kui teised maskeeritud: jõululaupäeva õhtul $(12.2,5)$, esimese püha hommikul (12.9), kolmanda püha hommikul (12.12), pühade ajal (12.3), käis jõuluks ja nääriks (12.14) või nääripäeva laupäeval $(12.34,44)$, vana aasta õhtul (12.26), vana-aasta öösel (12.23), uue aasta hommikust ööd (12.45), uueaasta hommikul (12.24), nääripäeval (12.41), uueaasta õhtul (12.33). Jõulukaru käis seega läbi jõulude - jõululaupäevast kolmanda pühani; näärikaru aga peamiselt nääriööl - õhtust hommikuni (nimetused küll vahelduvad, kuid aeg on ilmselt sama). Kolmekuningakaru käimise ajast pole andmeid peale ühe: kolmekuningapäe lauba ôhtu (12.50).

Karu oma kaaslasega - tantsitajaga - oli mõeldudki eeskätt nalja tegemiseks ja tembutamiseks. Karu tantsis üksi või kinni võetud talutüdrukuga (12.10), ajas inimesi taga ja püüdis neid kinni võtta (12.4), kui kätte sai, viis õlgedesse - rehetoa põrandat katsid jõuluajal õled (12.42), pööras voodiriided segamini (12.13), ähvardas lõhkuda kui ei kostitata (12.27), määris mustade käppadega nii inimesi kui riideid (12.36). Mõned näited:

... Teine poiss on taltsutaja, tal on kepp käes ja on karu nööripidi järele võtnud. Taltsutaja laseb karul rahvale tantsida. Karu tahab selle eest võid, mune ja saia. Talle antakse. Ta tahab ka tüdrukut magada. Talle lubatakse kui tantsib veel ilusti. Karu tantsib, siis antakse üks poiss kätte, karu võtab kohe ümbert kinni ja heidab ühes poisiga pikali... (12.20);

... üks paneb omale karvase kasuka selga, maski ette ja siis tolgendab neljakäpukil mööda tuba ringi. Kui ta hästi ei tee vigurid, selleks on siis suur pikk poom, millega karut peksetakse. Kui tants on läbi, siis peab 
iga peremees andma karutansu heaks midagi; kui midagi ei anta, siis saab "Näärikaru” vihaseks ja lõhub kõik, mis iganes ette juhtub... (12.27);

... peale kella 12, siis tuli mees sisse ja küsis pererahva käest: "Kas tahate näha väl'lamaa looma?” Talsutaja oli ja poiss oli, see läks sisse ja talsutaja tuli sisse ja aeas karul kaeru peale. Kaerad olid pähkled. Tüdrukute käest aeas pähkleid peale - need olid siis need kaerad. Talutamise jaoks oli üks löömariist ... 3-4 tolli jämedune... kaigas... Sellega andis siis karule paar müksu. Karu akkas siis tantsima... käpakil maas ta keis nel'la jala peal. Kui ta tansitas teda, siis oli kahe jala peal... Karu akkas niisugust äält tegema, siis talsutaja sai aru, mis karu tahtis ja ta küsis siis karule juua. See oli ükskõik kuidas - kas andsid tal pudelist viina või klaasi või toobiga õlut ka. Taltsutaja andis karule kätte... (12.50).

Lapsed mõistagi kartsid $(12.8,15,50)$, kuid hirmutamine ei olnud karude eesmärk (vrd hani!). Nagu teisi sanditajaid, nii tuli ka karu kostitada. Talle anti pähkleid, ka kaerteks nimetatud $(12.9,25,33,51)$, ounu $(12.16,39)$, ka mett karu tahab magusat (12.41), võid, mune ja saia (12.20), lihtsalt süüa (12.22, 27). Kostitamise hulka käis kindlasti õlu $(12.23,25,27,50,51)$ või viin $(12.25$, 50). Ainult ühes teates kõneldakse annetest, märkimata, mida just (12.22). Ühe 1939. a. teate järgi anti karule ka präänikuid ja kompvekke (12.25).

Kuigi karu tehti lõbustamiseks, kumab sellestki maskeeringust omaaegne usundiline taust. Nimelt pidi karu lapsetult arstima (12.39). Ka teade sellest, et karu viidi talli ja lauta, peletamaks kurja ja halba ning soodustamaks loomade kasvu (12.20) on tõsise sisuga, hoolimata naljatavast taustast.

1968. a-st märgitakse: lapsepõlves tehti, nüüd enam mitte (12.51) ja lausa vastandlikud: vahepeal kadus ära, nüüd käivad jälle (12.31, 49).

Üldiselt on tava hääbunud, vähemalt täiskasvanute ja noorukite lõbustusena. Laste maskeering pole karu olemasolevail teateil kunagi olnud.

\section{1.b.9. Kurg (13)}

Viimase enamlevinud maskeeringuna nimetagem kurge. Jõulukurest on 16 teadet aastaist

1930-1968, näärikurest 30 teadet aastaist 1929-1968 ja kolmekuningapäevakurest 14 teadet aastaist 1923-1968. Kureks maskeerijatest on vähe teateid. Mõned ütlevad, et tegijaks on vanamees $(13.6,23)$ või mees (13.17); enamus arvab tegijateks noored mehed $(13.25,28,29,33,42)$. Enamasti aga tegijaid ei märgita. Puudub ka vihje, et kureks käinud tüdruk või naine, mida linnumaskeeringu puhul võiks ju arvata. Ainult paari teate järgi tehtud kurge kodus, 

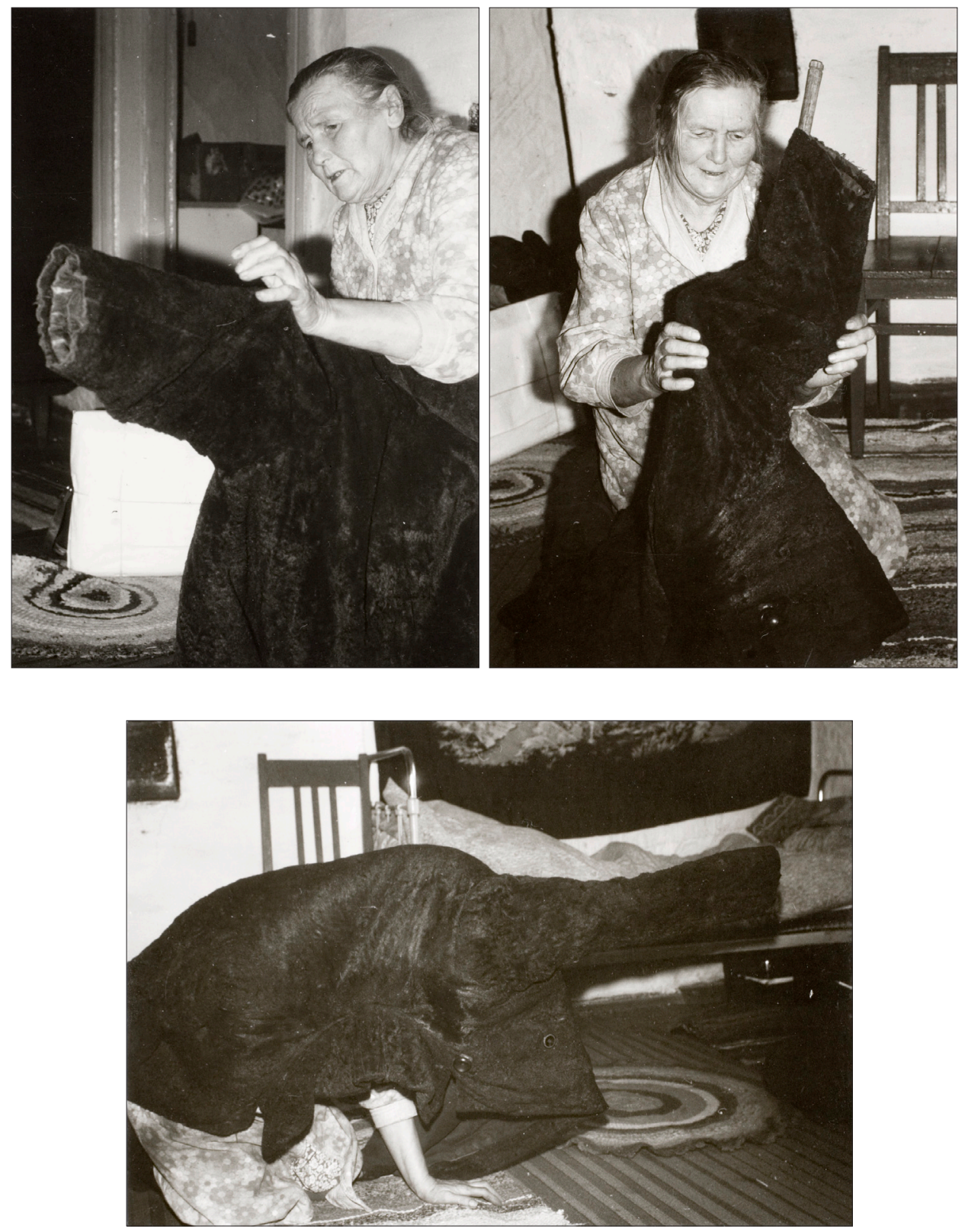

E. Holmik valmistab jõulukurge, Krasnojarski krai, Partisanski küla. Eesti Rahva Muuseumi fotokogu. 
oma pere lõbustuseks $(13.4,45)$. Maskeering oli lihtne: pahupidi kasukas ümber $(13.2,4,7,13,14,18,20,23,34,35,46,49,50,55-57)$, üks käis kasuka all, teine käis käega (või käisesse pistetud kepiga) kure kaelaks $(13.4,7,14,18$, 20, 34, 35, 40, 46, 49, 50, 55), peos kepp või kaks pilbast nokaks (vt eelmised ja 13.5). Mainitud on ka saba $(13.40,41)$ või vana vihta sabana $(13.18,41)$. Kohati on maskeeringut n-ö täpsustatud: nokaks punane kepp $(13.10,12)$; jalga on tõmmatud punased sukad imiteerimaks kure jalgu (13.10), kasutatud kitsaid pükse (13.7); kaelaks kasutatud kepi ümber on mässitud riie (13.3). Kohati on maskeeringut tunduvalt lihtsustatud: võeti valge riie (lina) ümber (13.10, 30) või üle pea (13.17), riide alt käsi väljas, kepp nokaks peos (13.17). On ka öeldud, kurg on nagu hani, ainult nokk on palju pikem (13.8) või pikk puust nokk $(13.28,29)$. Erilist hoolt on pööratud nokale, mis on tehtud kaheosaliseks ja liikuvaks - tõmmates paelaga noka alumist poolt käis see plaksatades kokku (13.30), mis mõistagi ehmatas või hirmutas külastatavaid. Arusaamatuks jääb vihje õlgkübaratele (13.38) kui kure tunnusele.

Kureks käidi kas eraldi - üksi või kaksi (13.6, 7, 9, 13, 17, 21, 22, 26, 47-50, 53-55, 57, 60), sest üksi oli igav käia, või siis koos teiste maskeeritutega. Eriti on esile tõstetud koos käinud sokku; karu ja kurge (13.18, 19, 28-30, 32, 39, $40,43,44)$ või ainult sokku ja kurge (13.33, 35-37, 42, 52, 58, 59). Veel on nimetatud sokku, kurge ja hane (13.1, 20, 23, 31); sokku, karu, hane ja kurge (13.15, 16); sokku, kurge ja tonti (?) (13.2); kurge, hane ja hobust (13.3); sokku, pukki, kurge ja tönki (?) (13.11).

Ka kure tegevuse hulka kuulus laste loetamine (13.2, 14); eraldi märgiti: laps, kes lugeda ei osanud, sai nuhelda (13.14), või üldisemalt laste hirmutamine $(13.4,13,41)$. Üsna levinud oli uuema-aegsest uskumusest - kurg toob lapsi - tingitud tegevus: kurg tõi kaltsudest nuku, mis poetati abielupaari - või tüdruku - sängi (13.1, 12, 17, 32, 40, 45, 54, 59). Ainult kord on märgitud, et nukk anti noorikule (13.32). Noorikuks nimetati teadupärast abielunaist kuni esimese lapse sünnini. Valitses arvamus: kui kurg astub tarre üle läve esmalt pahema jalaga, siis ta toob majja "peenikest peret" $(13.36,37)$. See oli kure tegevuse nö. spetsiifiline pool. Üldiselt oli kurg - nagu teisedki jõulusandid - seotud hullamise ja naljategemisega: ta ajas tüdrukuid taga (13.20), viis nooremaid õlgedesse (13.39), nokkis magajaid (13.47, 48), püüdis eest pagejaid nokkida (13.46); nokkis pererahvast kui andeid ei antud (13.35), torkas noka õllekannu - märguandeks, et tahab juua (13.55), nokkis laua pealt “vilja” - pähkleid ja muud, mis anneteks antav (13.57). Sanditajate tavaliselt tembutamisele viitab teade, et kurg hüppas ja laulis (13.10); maski omapärale see, et tuppa tulles teeb "kaak! kaak!" (13.27) või "kurluuks" (13.55) - kure häälitsuse imitatsioon. Vanematele usundilistele kujutelmadele viitavad teated, et kurg käis saunas (13.9) või tõi herneid (13.10). Saun oli koht, kus sünniti, põeti ja surdi; herned 
olid aga vana rituaalroog surnu valvamisel. Ka kurgi kostitati: õllega (13.9, 22), õlle-voonaga (13.18), pähklitega (13.18, 22, 31), ountega (13.31), präänikute-kompvekkidega (13.18). On antud ka andeid (13.1), lähemalt seletamata mida just. Ka jääb piiritlemata kure soovitud "marjakraam" (13.51). Annete kogumisele viitab kaasas olnud kotimees (13.31); tõsi - selle teate järgi käisid koos sokk, karu ja kurg. Ühe teate järgi aetud kurg kotti ja valatud veega üle (13.60). See Lutsi teade viitab kas Läti mõjudele või segunemisele hane tegemisega. Hane veega kastmine oli tavapärane.

Kurega seostuvad usundilised kujutelmad - hingelind, teise ilma (toone) saadik või esindaja (vt Loorits 1949: 348) - veenavad, et kureks käimine sobis hästi sellise siirderiituslikult olulise pühaga nagu jõulud ja et see tava võis olla vana. Tembutamine ja naljategemine - ühisjoon teiste maskeeringutega - on ilmselt hilisem ladestus. Jõulud olid ju hingedeaja lõpp (Loorits 1957: 186). Esivanemate hingesid võeti vastu saunas ja kurgki külastas sauna. Tähenduslik on seegi vihje, et kureks käisid vanad mehed. Tõsi, need vähesed viited tava põlisusele ja teatavale rituaalsusele mattuvad hiliste, noorte harrastuseks ja meelelahutuseks kujunenud kirjelduste alla.

\section{1.b.10. Tönk (14)}

Murdesõnade kartoteegi (EKI-s) järgi tähendab tönk midagi lühidat, nüri, kulunud, halvasti edenevat asja; ka tüügast ja juppi. Peamiselt Kihnus märgib ta kolli, hirmutiseks riietatud inimest, mida tehti pulmades, talgutel ja jõulu ajal. Laiemalt saartel ja Lääne-Eestis teataksegi jõulutönki ja nääritönki. Töngist on 15 teadet aastaist 1929-1975 saartelt ja Lääne-Eestist (erandina üks teade - 14.15 - on Vändrast). Otseseid teateid sellest, kes tönki tegid, ei ole. Kaudsetel andmetel võib väita, et tegemist oli meestega. Maskeering oli samasugune, nagu teistel jõulusanditajatel: sarved peas $(14.1,6,9,10)$, saba taga (14.9), habe lõua all (14.6, 9), tahmatud näoga (14.10), nokaga $(14.1,7,8)$ või puust tehtud plaksuvate lõugadega (14.9, 10); maskeeriti linnuks (14.15), riietati mardiks (14.12). Kadrisandid olla lahkumisel öelnud, et tulevad kahe nädala (?) pärast tagasi jõulutöngiks (14.3). Siin ilmselt tegemist eksimuse või väärtõlgendusega - vahe peaks olema neli, mitte kaks nädalat.

Ebamäärane on ka aeg, millal tönki tehti. On nimetatud jõuluaega (14.9), kolmekuningapäeva (14.5), viimase jõulupäeva - küünlapäeva (14.4); kasutatud nimetus viitab enamasti jõuludele. Ent on märgitud, et tönki tehti ka talgutel ja pulmades $(14.11,13)$ ning heina-ajal (14.13).

Tönk on valdavalt lastehirmutis $(14.2,6,9,10,13)$. Lapsi on ähvardatud: tönk viib ära (14.2), tönk on kurjem kui mardid (14.1). Kohati ongi nimetatud 
tönki lastetöngiks (14.11). See suhtumine on iseluumulik neile, kelle juures tönk käis. Töngiks käijad aga kontrollisid laste lugemisoskust (14.8, 9). Kui lastehirmutamine - teatava rahvapedagoogilise võttena - välja arvata, siis oli töngi tegemine naljatlev meelelahutamine. Sellele viitab ka jõulutönkide laul (Saaremaal ja Muhus), mis pole enam regivärsiline, vaid uuem, lõppriimiline:

Olgem rõõmsad, ôllekingid

juba laulvad jõulutöngid!

Need on tulnud teitid vaatma,

jõulupäivi mööda saatma,

õnnistavad elumaja,

soovivad, mis iial vaja!

Põhud parandal neil pingiks, sest naad hüitaks jõulutöngiks.

Kui te-ep too mull' ollekappa, siis mina suren teie tuppa.

Kirbud mulle kerstu teevad, täid ja lussud lusti löövad. (14.5, ka 4)

Ehkki seda teadetes ei öelda, võib kostitamist - vähemalt õllega - pidada enesestmõistetavaks. Hoolimata oma ebatavalisest nimetusest liitub tönk teiste jõulusanditajatega nii maskeeringult kui esinemiselt. Võib arvata, et tegu on üsna hilise tavaga, mis kujunes välja 19.-20. sajandi vahetusel või koguni alles 20. sajandil. Nüüdseks näikse tava olevat hääbunud.

\section{1.b.11. Muud jõulu- ja uusaastategelased (15)}

Lisaks eelnimetatud sanditajatele mainitakse pärimusteadetes veel mitmeid tegelasi ja nende maskeeringuid. Paraku on need vähelevinud ja mõnikord tunnukse uue nimetuse all vana tegelase ja maskeeringu variatsiooni. Atribuudid olid ju põhiliselt samad - kasukas, vaip või riidetükk, teivas otsa kinnitatud - ehtsate või puust voolitud sarvedega jne. Kujutatav maskeering ja selle nimetus oli suuresti kokkuleppeline. Kui sanditajate seltskond oli suurem traditsiooniliste maskeeringute arvust, siis improviseeritigi mõni uus maskeering uue tegelasega. Nii võib nimetada jõuluhobust (15.1, 10, 22, 28) aastail 1930-1948, kes käisid ringi jõuluajal (15.1) või vana-aasta õhtul (15.22). Hobust etendasid kaks meest: üks moodustas hobuse pea ja esimesed jalad; teine keha ja tagumised jalad (15.1, 10, 28); mõnikord oli veel kolmas ratsanikuks (15.28). Erandina on üks poiss hobust etendanud (15.22). Mõistagi oli ka hobune kaetud teki, kasuka või riidega. Tal oli õlest põimitud saba, millega lõi 
vastuvõtjaid, kui need - küllalt kiirelt - ei kostitanud sanditajaid õlle-viinaga (15.22). Hobust nimetatakse tavaliselt ikka teiste maskeeringute seltsis sokk, hani, kurg, hobune (15.10) või lisatakse kirjeldusele sõnakesed ka, veel, mis viitab teistelegi sanditajatele.

Teise seesugusena on nimetatud jõulukukke $(15.2,3,15,19)$ aastail 19301956, kes käinud jõululaupäeval (15.2, 3), näärilaupäeval (15.15) ja kolmekuningapäeval (15.19). Erandlik on olnud kuke funktsioon Väike-Maarjas: kingituste jagaja ja järgneva aasta viljasaagi ennustaja $(15.2,3)$. Mujal on kukk teiste sanditajate reas: sokk, karu, karutantsitaja, jõuluhani ja kõige viimasena kukk (15.15). Maskeeritud oli kukk nagu teisedki linnud - tõsi, nokk oli lühem. Esinemisse kuulus "pahade" nokkimine või kadakase sabaga vee pritsimine (15.15). Kõrvuti teistega sai ka kukk kostituste osaliseks.

On nn jõulumarte $(15.4,27)$ :

Jõulu teisel pühal käidi perest peresse. Käijatel olid lähkrid õlle korjamiseks kaasas. Nad laulnud nagu mardisandis (15.4 - Väike-Maarja 1930) ja

Riietatud mardisantidena, käidi teiste akende taga /jõululaupäeval/ (15.27 - Tori 1930).

Nendest pikemalt juttu ei ole. Seevastu Valgas teatakse jõulumärti, kes käib pikist õlgedest riided seljas (15.32 - 1930). Tagamaks õnne põllule ja sigadele, tuli jõulumärdile suur tanguvorst kaela visata. Lähedal eelmisele näikse teade:

Kolmekuningapäeval (õhtupoolikul) mässiti inimene õlgede sisse ja tehti talle õlgedest nuut kätte. See... käis mööda küla ja käis sees peaaegu igas talus. Kus inimesed veel ôlgedel pikutasid, anti neile tublisti nuuti (15.5 - Paldiski 1940).

See näikse olevat variatsioon töngile: Jõulu tehti tonti, kurge ja pukki. Pandi pahampidi kasukad selga. Raamat oli käes, pani lapsi lugema (15.6 - Nissi 1930).

Veel nimetatakse jõululutse (15.8) - nendest ei tea muud, et nokka pole olnud ja niisama hirmutasid (Pühalepa 1931). Juba hobuse puhul nimetati ratsutajat. Martnas seostub see sokuga: uue aasta hommikul tehti sokku. Siis ka ratsutaja. Selleks seoti väike puuhobuse moodi ese istmiku külge ja niiviisi kujutati ratsanikku. Ratsanik sõitis muidugi omal jalgadel (15.9 - 1968). Teade on hiline. Vististi oli vähe esinenud hobuse maskeering juba ununenud, kuid efektne ratsanik püsis mälus ja seostati populaarse sokuga.

Veel nimetatakse näärioinast, keda küsitletav samastab näärikaruga. Maskeering oli küllaltki keeruline: puust oinapea, silmade kohal punane paber, 
liikuvad lõuad, suu sees põlev küünal, karvane tekk ümber, vana viht sabaks. Oinas pidi olema palju lõbusam näärikarust ja pidi rahvale tantsima. Kui midagi ei antud, kastis sabaks oleva viha vette ja vihtles kõiki, kuni palk sai maksetud (15.11 - Lihula 1932). Ilmselt on oinaski kohalik variatsioon karust või sokust.

Helmest on teade jõulusiitsist: kuuseokstega ehitud tuli teisi taga ajama. Kes ette jäänud, see peksa saanud (15.31 - 1931).

Kihnus teatakse jõuluaegsete lastehirmutistena ööki (15.20) ja pööki (15.21), kelle maskeering tavapärane: karupidi kasukas, habemed suhu, puulõuad. Need näikse olevat töngi variatsioonid. Esimese kirjeldus lõpebki lausega "Siis lapsi narriti, et tönk tuleb" (15.20).

Erandlik on jõuluelevant (15.14) nii nimetuse kui teotsemise poolest. Elevant tehti õlgedest ja käidi sellega pähkleid norimas (Karuse 1938). Kirjeldusest ei ilmne, kas käidi külapidi või ainult oma peres. Mõistagi ei saa see ühekordne teade kajastada pärimust. Täpsemalt ilmneb selles jõuluaegne tava, rakendada üks loom kostituste kogumiseks.

Peresiseseks mänguks oli jõuluorika tegemine (15.12, 13, 23, 24). Seda tehti jõuluajal (15.12, 13), jõululaupäeval (15.23) või teisel pühal (15.24). Rehetuppa toodi jõuluks õled või heinad. Orikat tehti sedaviisi, et topiti kas vastastikku või ühel pereliikmel (naisel) riided heinu täis - kui ruumi enam polnud, oli orikas valmis. Siis anti orikale passidega (s.o õlest põimitud nuudid) peksa. Põhjust ei mainita, kuid ilmselt on tegu mingisuguse rituaaliga (näiteks karja õnneks). Täiesti analoogiline on jõulujõmmi tegemine (15.25, 26), ainult siin on objektiks väikene poiss, kellel topiti püksid heinu täis. Peksust pole juttu. See olevat "tuntuim jõulunali" (15.25).

Jõuluaegseist maskeeringuist küllap kõige erandlikum on surm:

Inime võttis sirbi kätte, kü̈̈nla hammaste vahele, rõivastus valgeisse rõivaisse... valge rätik pääs, nägu määrit jahuga (15.33).

Teade pärineb Lutsist ja viitab ilmselt katolitsismile (1933. a.).

Mitmed üksikteated on ka sanditajatest, kes käisid kolmekuningalaupäeval või kolmekuningapäeval. Esmalt nimetagem kolme tarka - kolm meest, kes käisid talust talusse rõõmsat kolmekuningapäeva soovimas (15.18). See on mõistagi Piiblist võetud ja tuntud Saaremaal, kus niigi kõige rohkem erimaskeeringuid. Paraku ei ole tarkade esinemisest ja riietusest üksikasjalikumaid teateid.

Teine, taas Saaremaal tuntud sanditaja oli kuul (s.o kalkun). Maskeering oli nagu teistelgi lindudel (15.17). On huvitav vahemärkus: pärast esinemist võttis kuul väljas kasuka ära ja tuli tuppa õlut jooma. Üks kiba õlut jäi ikka kolmekuninga ajaks, siis kuuludel oli ia juua. Lausest võib järeldada, et kuuluks käimine oli üsna tavaline. Paraku ei ole leidnud rohkem teateid. 
Kolmekuningalaupäeva öösel käis jahimees jäneste ja koertega (need olid pisikesed poisid). Jahimehel oli puupüss, igas peres lasi ühe jänese maha (15.16). Maskeeringust ja kostitusest pole teates kahjuks juttu.

Veel on teade meesterahvast, kes pani kitsesarved õlgkübara külge, kastis viha enne vette, siis tuha sisse ja ajas tüdrukuid taga (15.29, 30). Põhjus jääb ütlemata, samuti kostitus - millega vahest sai lahti osta.

Veel võib esineda n.ö. ülekandeid mardisanditamisest, näiteks näärisandid (15.34). Nende maskeering ja laulgi on mardisandile omale. Laul on lihtsalt mugandatud - seal kus peaks esinema, on antud redaktsioonis näärid. Tegemist on harvaesineva ülekandega.

Sellega on nimetatud kõik jõulusanditajad, kes on vähemal või suuremal määral tuntud üle Eesti ja esinevad jõulude ajal sõna laiemas tähenduses: kas jõuluajal, nääri ajal või kolmekuningapäeval, võimalik seegi, et kõigil nimetatud ajalõikudel. Vastava ainese laekumise ajal rahvaluule kogudesse oli tegemist juba selge meelelahutusega. Ometi võib ühe või teise maskeeringu puhul oimata kunagist rituaal-usundilist tausta. Tänaseks on need tavad juba hääbunud või hääbumas.

\section{1.b.12. Muud lokaalsed jõulu- ja uusaasta sanditajad (16 ja17)}

Edasi nimetagem jõulusanditajaid, kes on tuntud ainult seotuna kindla kohaga.

Tabanisandid, ka tabaniajajad on seotud stefani- ehk tehvanipäevaga (26. dets.). Päev on Eestis üldiselt vähetuntud või lausa tundmatu. Erandi moodustavad mõned külad Kuusalu kihelkonnas, Eesti põhjarannikul. Tegemist on küladega, mille elanikud - kohaliku pärimuse järgi - põlvnevad sinna asunud soomlastest (usutavasti Põhjasõja ajal või järel, kui eestlaste arv oli katku ja venelaste rüüste- ja taparetkede tagajärjel oluliselt vähenenud).

Tabanisantidest on säilinud põhiliselt nimetus ja lauluriismed. Vähestes teadetes on tava lootusetult segunenud (või samastunud) mardisanditamisega. Teadaolevalt vanim (käsikirjaline) teade ei nimeta sugu, kuid võib oletada, et tegemist on meestega, sest käidi „perest peresse, lähkrid seljas õlut ajamas“ (16.1); hilisem teade ütleb, et "mehed käisid viina norimas" (16.10). Enamasti tuntakse ainult laulu $(16.2,3,4,7,8)$, mida on pealkirjastatud "Tabani sandi laul" $(16.2,3)$. Maskeeringuks oli pahupidi kasukas (16.10). Ühe teate järgi tabanisante ei tunta (16.6). Käidi teisel jõulupühal (s.o tehvanipäeval) - täpsustamata, kas õhtul või päeval $(16.1,10)$. Ühe teate järgi käidi pärast jõulupühi (16.9). Viimases ilmneb eriti mardisanditamise mõju:

Käidi söökisid ja jookisid küla peal otsimas. Siis kogutud ühte talusse kokku ja söödud toidud koos ära. Tantsitud ka. Vanasti mängitud torupilli (16.9). 
Laulufragmentide järgi otsustades - ja silmas pidades, et Stephan oli hobuste kaitsepühak - oli tava eesmärgiks "hobuste õnne" edendamine.

J. Forseliuse järgi (Hiiemäe 1998: 289) oli Harju-Risti kihelkonnas tavaks hobustega ratsutada ja hobustel aadrit lasta - seda 1684. a. Fr. R. Kreutzwaldi kommentaaris umbes 200 aastat hiljem sellele teosele oli tava täiesti võõras. Seevastu G. Vilberg, kirjeldades Kuusalu tavasid 20. sajandi alguses, ütleb nimetatud päeva kohta: hobused aeti tarre, pakuti neile õlut, pesti õllega nende kõrvu. Õhtul tulid tabanisandid pahupidi kasukates ja kaetud nägudega, nuiates õlut ja viina. Tabanisantidel oli toas piiriks mida ei tohtinud ületada, nn tabaniõrs - seinast seinani ulatuv aampalk. Kui see piir ületati, aeti tabanid peksuga tarest välja.

G. Vilbergi kirjeldusest ilmneb, et enne Esimest maailmasõda oli tava kohati - veel üsna elav. Hilisemad arhiiviandmed aga näitavad tava kiiret hääbumist. Ju oli kandepind liialt kitsas.

Kristoslaavitajate tavast on kasutada 37 teadet aastaist 1927-1980 (kõrvale on jäänud 5 kogu, kuna selles on raske eristada autentset materjali koopiatest või võltsingutest). Esineb nimetusi: krestoslaavitaja (17.37), krõstoslaavitaja (17.27, 29), kristos-krõstoslavtaja (17.10, 31), kristoslavitaja (17.11, 12, 14), kristotaja $(17.32,34)$ ja viinagraaditaja (17.26). Tava ja nimetus on vene laenud erineval mugandusastmel. Käijateks olid: viie-kuueaastased lapsed $(17.8,16$, $17,20,22,23,30,33,34)$, lapsed ja vanad mehed (17.28, 32), väikesed poisid $(17.4,21,25,31)$, poisid $(17.2,9,12)$, või noored inimesed $(17.16,17,35)$; ka vene poisid (17.15, 18). Käidi mitmekesi, kuni kuus lauljat (17.6, 7, 27, 35).

Käidi jõuluööl (17.5, 11, 35), jõululaupäeval öö läbi (17.3, 20, 25, 27), esimese püha hommikul (17.9, 10, 22, 31), esimese püha öö läbi (17.6), jõulu ja uueaasta hommikul (17.2), öösel jõulude ajal (17.33). Maskeeringust ei ole teateid (kahel korral - 17.26 ja 37 - mainitakse: imelikult või moonutatult riides), küll aga atribuutikast.

Kristoslaavitajad kandnud värvilisest paberist laternaid, mille sees põlev küünal $(17.9,11,12,15,17,20,21,23,27)$; kepi otsas Petlema tähte - sõelakerest või papist, küünal sees $(17.3,13,16,27)$; käes risti ja küünalt (17.2, 33), erandlikult: ahjuluuda ja leivalabidat (17.26). Viimase puhul võib tegu olla venelastest kristoslaavitajate kantud esemete vale tõlgendusega. Akna taga või toas lauldud laul $(17.29,35)$ on vaimuliku sisuga, teavitades Kristuse sündimisest. On üks laulutekst (17.1), mis viitab otsesele mardilaulu mõjule (palutakse andeid). Martidele viitab ka tava, lauljaid lauda kutsuda - muidu sajatati (17.24). Päris üldiselt anti lauljatele tasuks raha (17.2, 3, 6-11, 14, 25, 27, 30-32, 34-36); on ka irooniliselt märgitud - teismeliste puhul - et „suitsuraha“ (17.17). On teateid annete eristumisest: lastele anti raha, vanadele süüa (ja viina) $(17.14,33)$. Ilmselt segunemisele mardikommetega viitavad söögikraami andmised: saia (17.8, 30), jõulutoite (17.11), maiustusi (17.16). On öeldud 


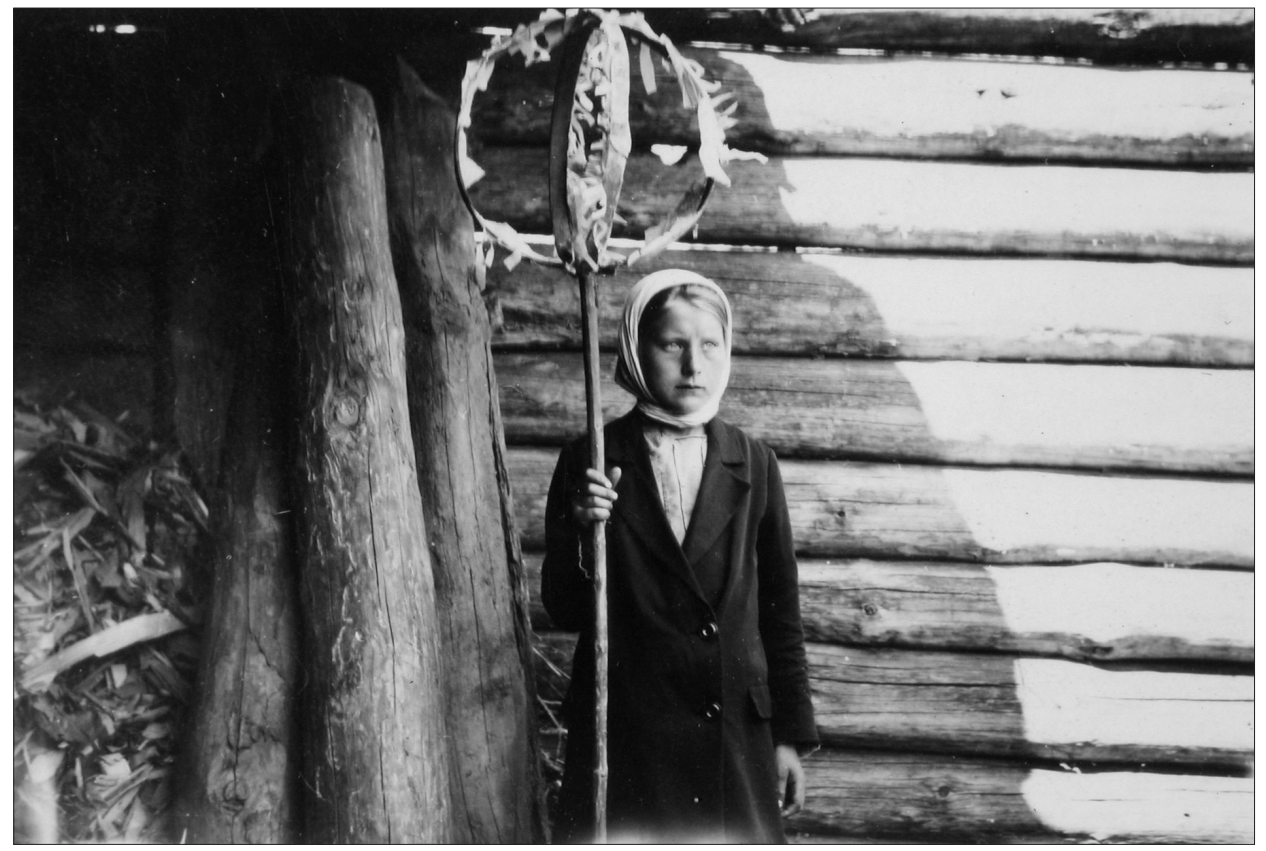

Paberlaternaga krõstoslaavitaja Setumaal, 1935. Eesti Rahva Muuseumi fotokogu.

ka, et anti igasugu andeid (17.22) või midagi anti (17.18). Tegemist on vene õigeusu rahvapärastatud tavaga, mida kohtame ainult Setumaal, Kagu-Eesti nurgas, ehkki õigeusulisi esineb mujalgi Eestis. Tähelepanu väärib asjaolu, et teadetes rõhutatakse venelaste esinemist tavas (17.15, 18, 26, 29). Ka laul olnud venekeelne (17.34).

\section{3.c. Jõuludele järgne periood}

\section{3.c.1. Nuudipäev - 7. jaanuar (18)}

Nuudipäev oli jõulude lõpupäev (Hiiemäe 1998: 307 jj). Kuna nuudipäev oli vähetuntud tähtpäev, siis samastati ta mõnikord kolmekuningapäevaga (18.5, 9, 34), mis oli ju laiemalt tuntud jõululõpetusena. Valitses ka arvamus, et nuudipäev on iga püha järgmine päev, n-ö pühade pikendus (18.32). Nii pole imestada, et nuudipäevaks peeti jõulude või nääripäeva järgmist päeva (18.12, 14) või süütalastepäevale - 28. dets. - järgnevat päeva (18.20, 26). Enamasti on aga vähesed teated - 34 teadet aastaist 1924-1980 - seostatud õige kuupäeva- 
ga. Nuudipäev on tuntud reeglina Lääne-Eestis, eriti just Hiiu- ja Saaremaal. Nuudipäeval käisid mööda küla ringi nuudid (18.6, 10, 13, 19, 22-26), paha nuut (18.15) või nuudipoisid (18.20). Sageli aga ringikäijaid eraldi nimetusega ei tähistata.

Nuudiks käisid poisid $(18.4,15,20)$, noored mehed $(18.3,4,8,14,17)$, mehed $(18.1,15,22,23)$ ja vanad mehed (18.29). Ühe teate järgi (18.16) käinud nuudipäeval külas “naised valges riides”. See Karja kihelkonnast a. 1980 pärinev teade segab ilmselt nuudid lutsidega - komme oli juba hääbunud, mõlemal juhul oli tegu nn jõulusantidega: lutsid enne, nuudid pärast jõule - nii võis pärimuse meenutamisel kergesti juhtuda eksitus. Keerulisem on lugu Mustjalast pärineva teatega a. 1974, kus väidetakse, et Ninase külas käisid nuudiks naised, õlevihk seljas (18.25): "Ühest perest tulid, läksid teise perese jälle, panid see ölevihu maha ja istusid peale ja jöid ja läksid teise perese jälle”. Kinnituseks oli väide, et Ninasel pole vanu inimesi. Kas hoidsid naised pärimust, milles algselt osalesid vanad (mehed)? Igatahes on see ainuke teade naisnuutidest.

Erilist rõivastust või maskeerimist ei nimetata. Kord on mainitud, et pajuväät (18.2); kord, et õlest nuut on seotud ümber keha (18.15). Küll aga on rõhutatud õlgedest punutud nuudi käes või seljas kandmist (18.2-4, 12-14, 17, 19-22) või nuudi tegelikku kasutamist (18.1, 5, 7, 8, 27, 28, 31). Ühe teate järgi nuut põimitud hernevartest (18.31). Nuute oli mitu.

Nuudiks käimise eesmärk oli pühade lõpetamine. See on hargnenud kaheks toiminguks: pühade õlle lõpetamine ühelt poolt ja pühade nö. väljapeksmine teiselt poolt. Esimest iseloomustab teade: nuudid käisid õllenõu punne otsimas $(18.10,11,15,19,21,22)$, punnid keeratud õlenuudi sisse $(18.19,22)$ või koguti kaelas olevasse kotti $(18.15,21)$. Ollenõu vikkide või punnide kogumine taandus viimase õlle ühisjoomiseks $(18.4,23,26,29)$ või koguni õlle otsimiseks $(18.8$, $9,12)$. Punnide kogumisega kaasnes ka õlle maha laskmine (18.13, 25), mida usutavasti tuleb mõista metafoorselt - vaevalt et õlut maha valada, küllap see pigemini ära joodi (arvestades eestlase üldist säästlikkust). Iseloomulik on riimiline nuutide lausung:

\section{Me käime perest perese \\ ja aame ôlut kerese! (18.12).}

Kuidas pühade väljapeksmine tegelikult toimus, selles teateid pole, küll on nimetatud pühade ära ajamist $(18.3,8)$, jõulude välja peksmist $(18.4,30)$, külaliste ja põhkude - s.o metafoorselt pühade - välja peksmist (18.20). Huvitavad on metafoorsed teated: nuut peksab õlle välja, annab taari asemele $(18.7,20)$ ja: paha nuut peksab lihapudi välja ja annab taaripudi asemele (18.27). Siingi tuleb õlle ja lihapudi asemele mõelda pühi. Jõulude ajal oli ju toidulaud taludes tavapärasest rikkalikum. 
Pole imestada, et sümboolne pühade väljapeksmine on muutunud esimese ettejuhtuva (18.2) nuutimiseks. Ent nuutidega peksti ka pererahvast (18.5) või vastastikku teineteist $(18.28,31)$. On öeldud sedagi, et nuuti sai see, kes väga vinti jäi (18.12). Ja paistab, et kombe hääbumisel mindi kõrtsi, kus teineteist nuutidega peksti (18.1), tantsiti ja joodi (18.8, 12). Mustjalast on teateid, et nuudipäeval tantsisid vanad ja noored Mustjala rongi (18.18, 19, 22). Fikseeritud on ka nuutide laul (18.24), millest rohkem teateid pole. Üldine seisukoht oli: nuut liivapulk viib jõulud (18.33).

Komme on hääbunud. Ilmekas teade: Vanaste peeti nuuti, minu isa on seda rääkin, et nuudiks käidi (18.6).

\section{Kokkuvõtteks}

Sellega on ülevaade jõulusantidest ammendatud. Jõulusandid, need, kes käisid peresid mööda jõululaupäevast kolmekuningapäevani (v.a. tabanisandid ja kristoslaavitajad), olid algselt ühtsed. Jagunemine jõulu-, nääri- ja kolmekuningasantideks on pühade eristumise tulemus ja suhteliselt hiline nähtus. Andmete rohkus ja levik annavad alust väita: vanemad on looma- ja linnumaskeeringud. Vanim on ilmselt sokk või pukk. Pole võimatu, et see maskeering oli käibel juba enne kristianiseerimist. Hani, kurg ja karu on sokust hilisemad, kuid kindlasti vanemad kui inimsandid. Viimaste, eriti jõulueelsete santide andreste, lutside, toomaste - puhul tuleb arvestada ühelt poolt rootsi, teiselt poolt kohaliku mardi-kadri-pärimuse eeskuju ja mõju. Jõuluaegse sanditamise tipp-periood näikse olnud 19. sajandi teisel poolel. 20. sajandil hakkas pärimus kiiresti taanduma. Asemele astus rahvusvaheline jõuluvana (meil ajastu nõudel näärivana). Jõulusandid - nii arvukuse kui ka leviku poolest - olid eriti tuntud Lääne-Eesti saartel. Mida ida poole, seda ahtamaks muutub vastav traditsioon. Otsesed laenud - tabanisandid Kuusalus, kristoslaavitajad Setus - jäid lokaalseks erijooneks, suutmata tungida laiemasse pärimusringi. Võib öelda, et jõulusanditamine oli suures osas külanoorte (eriti poiste) meelisala. Pühad ja sanditamine olid tihedalt seotud: sandid teatasid a) pühade saabumisest, b) pühade n-ö "olemasolust" ja c) pühade lõppemisest. Seegi viitab jõulude olulisusele eesti pärimuses. 